UNITED STATES DEPARTMENT OF THE INTERIOR

Harold L. Ickes, Secretary

GEOLOGICAL SURVEY

w. C. Mendenhall, Director

Bulletin 909-C

\title{
GEOPHYSICAL ABSTRACTS 94
}

\author{
JULY-SEPTEMBER 1938
}

\author{
COMPILED BY \\ W. AYVAZOGLOU
}

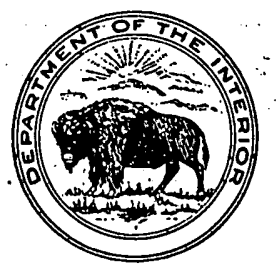

UNITED STATES

GOVERNMENT PRINTING OFFICE

WASHINGTON : 1939 


\section{CONTENTS}

1. Gravitational methods

2. Magnetic methods__._-_._- 110

3. Seismic methods_-_-_-_-_-_- 113

4. Electrical methods_-_-_-_-_-_-_- 125

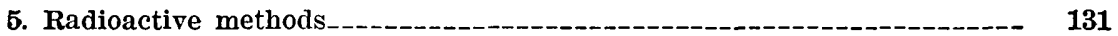

6. Geothermal methods.-_- 133

7. Unclassified methods_-_-_- 134

8. Geology-_-_. 140

9. New books_-_- 141

10. Patents ....- 143

Index -...-...- 149

Nort.-Geophysical abstracts 1-86 were issued in mimeographed form by the Bureau of Mines. Later abstracts have been published in bulletins of the Geological Survey as follows: No. 87, July-December 1936, Bulletin 887; Nos. 88-91, January-December 1937, Bulletin 895, A-D; Nos. 92-93, January-June 1938, Bulletin 9.09, A-B.

II 


\title{
GEOPHYSICAL ABSTRACTS 94, JULY-SEPTEMBER 1938
}

\author{
Compiled by W. Axvazoglou
}

\section{GRAVITATIONAL METHODS}

4425. Baziuk, R. M., Torsion balance with two inclined beams "S-20/2" according to Numerov-Schweidar [in Russian]: Bull. Neftianoy Geoflziki, no. 3, pp. 137-150, Moscow, 1936.

A detailed description of torsion balance S-20/2, no. 821, developed from Numerov's torsion balance with three beams and Schweidar's with two beams, is given. The balance is manufactured by Askania Werke

Results of fleld and laboratory tests had shown that the operation of the balance is simple and the damping of the torsional system requires only 20 minutes. Although this balance is less accurate than a type $\mathrm{Z}$ balance, it is considered adequate for field work. $-W . A$.

4426. van Bemmelen, $R$. W., The distribution of the regional isostatic anomalies in the Malayan Archipelago: De Ing. Nederlandsch-Indië, vol. 5, no. 4, pp. 61-67, Bandoeng, 1938.

A partial reconstruction of the gravimetric map of the Malayan Archipelago, made by Vening Meinesz, and the introduction of two auxiliary isonomaly-lines for +20 and +35 milligals reveal that one is not justified in dividing the positive anomalies of this region into two genetically different groups, e. g., (1) strips of positive anomalies parallel to the main axis of negative anomalies, and (2) fields of positive anomalies coinciding with subsiding troughs.

The isostatic anomalies of the Malayan Archipelago form a uniform and genetically connected group. The centre of disturbance of the isostatic equilibrium is situated in the main axis of negative anomalies. From this zone parallel waves of positive anomalies emanate, showing a decreasing intensity the farther they are away from this central zone.

The main belt of negative anomalies is directly connected with a feature of the crustal surface, viz, the rising chain of outer arcs of the Soenda Mountain systems, whereas the positive zones are not directly connected with the surface relief. This feature cannot easily be explained by the conception of the compression theory (formation of mountain roots by the buckling of the earth's crust), but it finds a sound and consistent explanation in the conception of the undation theory (disturbance of the hydrostatic equilibrium in the subcrustal layers by magmatic differentiation in the grand style).-Author's abstract.

4427. Benfleld, A. E., A static gravimeter: Royal Astron. Soc., Monthly Notices, Geophys. Suppl., vol. 4, no. 5, pp. 351-359, London, 1938.

An unsuccessful static gravimeter is described, and details of design and procedure are given, in order to guide others who may consider constructing an instrument of the same type. The principle employed is barometric, in a form similar to one used previously with reported success (see Geophys. Abstracts 90, nos. 3809 and 3810). It was thought that the instrument described in this article would be an 
improvement, but the irregularity of the surface tension of mercury proved to be an insuperable difficulty. No way of overcoming the trouble without introducing further difficulties was found.-Author's abstract.

4428. Daly, R. A., The strength of the earth's outer shells: Am. Jour. Sci., 5th ser., vol. 35, no. 210, pp. 401-425, New Haven, Connecticut, 1938.

According to a suggested model for the earth a considerable part of the isostatic support of continents and high mountains is located in "anti-roots." The gravity anomalies, computed on the assumption that this model is correct in principle, would differ but little from Hayford anomalies at the respective stations. Hirvonen's new values of gravity at 202 stations in the glaciated tract of northwestern Europe indicate extremely small, if not zero, strength in the asthenosphere. Most of the flelds of one-sign Hayford anomalies, computed by the 1930 International formula for the figure of the earth, seem to demand strength in the lithosphere of the same order as that calculated by Barrell and Jeffreys. On the other hand, the fields of peninsular India, interpreted on the same basis, would mean a highly improbable degree of strength for the lithosphere. This difficulty with the proposed earth-model is removed if we assume for the geoid a triaxiality of the kind deduced by Helmert, Berroth, Heiskanen, and Hirvonen.-Author's abstract.

4429. Ewing, Maurice, Marine gravimetric method and surveys: Am. Philos. Soc. Proc., vol. 79, no. 1, pp. 47-70, Philadelphia, Pennsylvania, 1938.

After a brief outline of gravity measurements made during several voyages on sea the author discusses the subject under the following headings: (1) Development of the Meinesz apparatus. A description is given. (2) Summary of surveys using the Meinesz method. A table is given including all marine gravity surveys known to the author on which the Meinesz apparatus, or instruments of other design embodying the principle of the fictitious pendulum, have been used. (3) Modification of Meinesz apparatus by later workers. Devices for damping free vibrations of the pendulum case and method of timing the pendulums are described. (4) Second order disturbance terms. A correction involving second order terms for disturbances caused by motions of the ship is necessary. The principal disturbances for which this correction is needed when observations are made on a submerged submarine are those caused by very long waves. or swells. (5) Negative gravity anomalies-Meinesz belts. A long narrow belt of large negative gravity anomalies, called the Meinesz belt, was found in the East Indies and was elaborately mapped by. Meinesz in the years 1926-29. It is shown in two gravity maps of the East Indies. Another belt is associated with the Nippon trench, as shown in the gravity map of that trench. (6) Positive anomalies over the oceans. Some positive anomalies of gravity were found over the oceans. They are much smaller than the negative anomalies. (7) Static gravity meters for marine measurements. An outstanding difficulty for all static gravimeters for marine measurements is that they are not, as a rule, as free from shifting of the zero-point as pendulum instruments. (8) Gravity measurements in polar regions. An important contribution to r:arine gravity surveys is now being made by the floating expedition of the Union of Soviet Socialist Republics as it promises gravity data in a region where observations are badly needed. (9) Relation to isostasy and the 
figure of the earth. The results of the marine measurements have provided a direct confirmation of the principle of isostasy. A list of $\mathbf{3 7}$ references is added. $-W . A$.

4430. Gavat, $I$., Sur les anomalies du gradient horizontal de " $G$ " aux confins des Subcarpates et de la plaine Roumaine au point de vue de la prospéction du petrole [On the anomalies of the horizontal gradient " $G$ " at the borders of the sub-Carpathian mountains and the Rumanian plain from the viewpoint of prospecting for oil]: Moniteur du Pétrole Roumain, vol. 39, pp. 347-358, no. 5, Bucharest, 1938.

After a geomorphic and geologic description of the zone between the valleys of the Dambovitsa and Trotush Rivers, the results of an extensive gravimetric survey made by the Rumanian Geological Institute from 1928 to 1936 in the region of Ploeshti-Targovishte are described. Results or torsion balance measurements made at 3,000 stations, covering an area of about $1,300 \mathrm{~km}^{2}$, are shown on maps and profiles.-W. $A$.

4431. Howe, H. H., Note on effect of torsion in QHM observations: Terres. Magn. and Atmos. Electr., vol. 43, no. 2, pp. 167-168, Baltimore, Maryland, 1938.

The quartz horizontal-intensity magnetometer ( $Q H M$ ) consists of a magnet and mirror suspended by a quartz fiber mounted on a theodolitebase. Using approximations to the trigonometric functions involved, a simple expression is obtained for the error resulting from imperfect elimination of initial torsion in the fiber.-W. $A$.

4432. Jung, Karl, Über vollständig isostatische Reduktion [On the total isostatic reduction] : Zeitschr. Geophysik, vol. 14, no. 1/2, pp. 27-44, Braunschweig, 1938.

The mathematical foundation of the "total isostatic reduction" is developed. It is shown that gravity values reduced fully isostatically may differ considerably from those reduced according to the PrattHayford and Airy-Heiskanen hypotheses, and that the consideration of the total isostatic condition is by no means only an insignificant correction. The estimation of the total isostatic anomalies is especially evident from a number of Vening Meinesz's profiles. These profiles show the excess weight of the oceans to be more marked than previously supposed. Great anomalies remain in general without change; but the details of the deviation from the floating equilibrium may be considerably different from those expected based on the calculations made thus far. Definite conclusions concerning the forces acting in the earth's crust can hardly be drawn without total isostatic reduction.-Author's abstract, translated by W. A.

4433. Lagrula, Jean, Valeurs de la gravité au Sahara et au Soudan [Values of gravity in the Sahara and the Sudan] : Acad. sci. Paris Comptes rendus, vol. 206, no. 21, pp. 1553-1555, 1938.

Locations of the 58 stations and values of the intensity of gravity as determined at these stations by the Holweck-Lejay pendulum are shown in a table. $-W . A$.

4434. Liustikh, E. N., Simple mechanical integrator for calculating $G$. [in Russian]. Bull. Neftianoy Geofiziki, no. 4, pp. 68-71, Moscow, 1937.

An instrument is described for approximate calculation of the vertical component of the force of gravity ( $\mathrm{G} x$ ) produced by a body of known form, provided the outline of this body is given in contour lines. $-W$. $\boldsymbol{A}$. 
4435. Mader, Karl, Die Anwendung der Schwerkraftmessungen auf Geologie und Bergbau in Österreich [Application of gravity measurement to geology and mining in Austria]: Berg-. u. hüttenm. Monatsh., vol. 86, no. 4. pp. 67-74, Vienna, 1938.

Deficiency in gravity over an area of large extent in the eastern Alps was disclosed by gravity measurements. This was best explained by the conception that the visible Alps down to a depth of about $\mathbf{3 0}$ $\mathrm{km}$ consist of a material lighter than that of the earth's crust at similar depths. The form of the surface of the geoid from the Baltic Sea to Innsbruck and beyond, as determined by the astronomical survey, can also be represented mathematically only by assuming mass deficiency below the Alps.

Profiles of primitive rocks mapped by $R$. Schumann with the torsion balance to the south of Vienna resulted in the discovery of natural gas; structure important from the miner's viewpoint was further extended by Governmental survey, and the gravity net in Marchfeld was considerably condensed. Possible application of the torsion balance in mining is discussed.-Author's abstract, translated by W. A.

4436. Neumann, Frank, Simple torsion pendulum as an accelerogram analyser: Union géod. géophys. internat., Travaux sci., no. 15, pp. 208-216, Toulouse, 1937.

The method described makes it possible to determine quickly the motion of any other type of pendulum from the record of an accelerograph. A general description is given of the function of the torsion pendulum as an analyser. The set-up of the apparatus and the theory of it are supplied. With the torsion pendulum analyser some of the more difficult problems are avoided, particularly with regard to the zero position.-R. S. R., Sci. Abstracts, vol. 41, no. 485, 1938.

4437. Schander, Johannes, Die geologische Bedeutung von Gravimetermessungen [Geological significance of gravimeter measurements] : Bohrtech. Zeitung, vol. 56, no. 6, pp. 81-85, Vienna, 1938.

Practical importance of gravity measurements for obtaining information on geological structure is discussed. A map of gravity anomalies in Schleswig-Holstein published by Barch in 1936 is given. Grossstructure determined by gravity anomalies is assumed to be the result of the effects of deep earth stockworks. This assumption can be proved only when sufficient data on the pre-Mesozoic formations of this area are available from very deep borings. Relation of gravity structure to horst ranges and salt domes is proved by seismic data. Three great positive gravity anomalies are shown in the map; they are: (1) the Central Schleswig-Holstein Scholle (block faulting); (2) the small belt Scholle; and (3) the Hamburg-Kiel Scholle.-W. A.

4438. Schwinner, Robert, Das Problem der Isostasie [The problem of isostasy] : Geol. Rundschau, vol. 29, no. 1/2, pp. 1-26, Stuttgart, 1938.

After a brief discussion of various theories of isostasy, an attempt is made to determine the relation between the structure of the earth's crust and its gravimetric attitude. For better understanding of the problem the structural features of the earth's crust are divided into typical groups as: (1) Swiss type of mountain ranges, characterized by great structural complications; (2) Block mountains; (3) Shear structure (Abscherungsdecke) ; as an example of this type the Upper and Lower Austrian calcareous Alps are mentioned; (4) Regions where 
mountains have been removed by erosion; (5) Saxonic blocks of north Germany (Saxonischen Schollen Norddeutschlands); (6) Formations found by Vening Meinesz on the East Indian archipelago, characterized isostatically by negative anomalies of gravity; (7) Buried mountain ranges (Verborgene Gebirgskette) as determined by Indian geodesists; and (8) Volcanic mountains.

The conclusion is drawn that for the solution of the problem of isostasy it is at present very important to obtain more information concerning the relation between gravity and structure of the earth's crust. $-W . A$.

4439. Senko, A. K., Contribution to the interpretation of gravitational observations by the method of integral equations [in Russian]: Bull. Neftianoy Geoflziki, no. 3, pp. 151-152, Moscow, 1936.

Mathematical discussion of the problem of interpretation of gravitational observations is given for the case when the relief to be determined is known in its first approximation.-W. $A$.

4440. Shwank, O. A., General solution of the direct gravimetric problem concerning some two-dimensional bodies [in Russian]: Bull. Neftianoy Geofiziki, no. 4, pp. 54-67, Moscow, 1937.

Formulas are derived by which it is possible to calculate the values $\frac{d^{2} v}{d x d z}, \frac{d^{2} v}{d x^{2}}$ for the gravitational field of a two-dimensional body the cross section of which is a layer of arbitrary shape extending to infinity. Single cases are discussed for which these formulas reduce to a form commonly used in calculations. It is shown how formulas for a twodimensional body in trapezoidal or triangular cross section may be obtained from these formulas.-Author's abstract, translated by W. A.

4441. Steinmann, $K$. W., The various phases in torsion balance work: Oil Weekly, vol. 89, no. 8, pp. 19-23, Houston, Texas, 1938.

Photographs showing successive phases in torsion balance work are given: (1) A surveyor taking terrain; (2) the instrument truck arrives at the station site; (3) the selected. observation site; (4) the partly erected hut; (5) the instrument base and middle part are set up on the base plate; (6) the instrument proper is carried to the tent; (7) the assembled equipment ready for operation; (8) the tent completely mounted; (9) torsion balance record; and (10) flnal torsion balance picture.-W. $A$.

4442. Vening Meinesz, F. A., The gravity expedition of $H$. M. Submarine $O \mathbf{1 6}$ in the North Atlantic, January 11-March 16, 1937: Royal Acad. Sci. Amsterdam Proc., vol. 40, no. 5, pp. 382-389, 1937.

A map shows the route of the submarine and the locations of 93 gravity observations taken with the old multiple pendulum apparatus. Only a few observations have been computed, but the author hopes that the final computations will yield much information about the positive anomalies in the deep basins of the North Atlantic.-W. $A$.

4443. Vening Meinesz, F. A., Second order disturbance terms in pendulum observations at sea : Royal Acad. Sci. Amsterdam Proc., vol. 40, no. 8, pp. 650-653, 1937.

Second order terms of the disturbances caused by the ship's movements cannot be neglected even for measurements in submerged submarines, as they may attain values of more than 10 milligals accord- 
ing to investigations made recently by B. C. Browne (Royal Astron. Soc. Monthly Notices, Geophys. Suppl., vol. 4, no. 3, see Geophys. Abstracts 92, no. 4108).

Two points are considered: (1). Whether the accelerations can be determined; and (2) whether the earlier gravity data at sea can be corrected for them. The determination of the vertical accelerations does not present a serious problem, and a formula for computing the correction is given. To determine the horizontal acceleration is more difficult. Experiments are under way to do this by installing on the gravity apparatus a slow pendulum with a longer period than that of the horizontal accelerations.

In general the correction of the gravity results appears to be less than one milligal and in relatively few observations does it exceed a few milligals. $-W . A$.

\section{MAGNETIC METHODS}

4444. Bartels, J., Erdmagnetische Aktivität [Earth magnetic activity] : Terres. Magn. and Atmos. Electr., vol. 43, no. 2, pp. 131-134, Baltimore, 1938.

The tables of monthly and annual means for the measures $u$ and $u_{2}$ of terrestrial-magnetic activity given in this journal for the sears since 1832, are continued for the years 1935 and 1936, and supplemented by preliminary values, based on observations at Niemegk alone, up to March 1938. The recent sharp increase in magnetic activity is discussed and compared with the Zürich sunspot numbers $R$. The lag of $u$ behind $R$ is again noticeable. 1937 appears to be the most active year magnetically since the years around the high sunspot-maximum 1870 , although no individual storm of outstanding intensity occurred. Three successive storms gave the high value $n=2.74$ to the month January 1938, a value comparable only with such well-known months as November 1882, August 1917, March 1920, or May 1921. The different degree of terrestrial-magnetic quietness reached during the last four sunspot minima is discussed. The minima of 1901 and 1913 were appreciably quieter than the minima of 1923 and 1933; this magnetic evidence agrees with solar observations insofar as the sun was free of spots on more days around 1901 and 1913 than around 1923 and 1933.-Author's abstract.

4445. Bartels, J., and Fanselau, G., Geophysical lunar almanac: Terres. Magn. and Atmos. Electr., vol. 1/3, no. 2, pp. 155-158, Baltimore, 1938.

This is a translation from German of the first part of the article deposits in the Angara-Ilim region [in Russian]: East Siberian Geol. physik, vol. 13, no. $7 / 8,1937$. An abstract of the article is given in Geophys. Abstracts 93, no. 4374.-W. A.

4446. Bersudsky, L. D., On the causes of the inverse polarity of magnetite deposits in the Angara-Ilim region [in Russian]: East Siberian Geol. Trust Trans., no. 2, 69 pp., Irkutsk, 1937.

In nearly all of the numerous magnetic investigations made in the region of Angara-Ilim, an inverse polarity in the sense of direction was observed in the magnetite ore deposits of this region. An attempt is made to explain this extraordinary phenomenon by detailed studies of geologic and petrographic material and by data obtained from magnetic observations. 
The following six hypotheses on the possible causes of the abnormal polarity are examined:

1. Tectonic hypothesis-suggests great tectonic disturbances. The hypothesis is rejected as the tectonic manifestations in this region are known to be of purely local character.

2. Mercanton's hypothesis of the change in the direction of the earth's magnetic field in the Tertiary rocks. The abnormal polarity could not be explained by this hypothesis.

3. Assumption of the magnetization of the deposits by magnetic fields produced by lightning discharges. This hypothesis is rejected as the suggestions for the application of it seem impracticable.

4. Spontaneous magnetization of ores on cooling. The available data could not explain the intensive negative anomalies on this assumption.

5. The supposition of diamagnetism of ores or of some special magnetic properties of magnetites of Angara-Ilim could not be confirmed by the analysis of the samples which proved to be in their essential features very similar to other magnetites.

6. The most probable hypothesis is that the abnormal polarity is caused by induction due to the action of the enclosing rocks in the magnetite during the process of formation of magnetite dikes.

A proof of the possible origin of the inverse polarity of the magnetite dikes as a result of the influence of induction of the adjacent magnetite masses would be of great value: (1) for the methods of interpretation of magnetic anomalies; (2) for the application of magnetic prospecting to magnetite deposits; and (3) for the explanation of many areas with negative intensity, which could not be explained by former magnetic surveys. $-W$. $A$.

4447. Bosler, Jean, Courants telluriques et perturbations magnétiques [Terrestrial currents and magnetic disturbances] : Acad. sci. Paris Comptes rendus, vol. 206, no. 13, pp. 964-966, 1938.

A striking parallelism between the curves of the magnetic disturbances and the terrestrial currents, as recorded at the Parc Saint-Muir Observatory during a great number of years, is evideut.

These curves point, therefore, toward possible establishment of a tenable theory concerning the relationship between these two phenomena. The question of the origin of terrestrial currents remains, of course, still unsolved. $-W . A$.

4448. Éblé, Louis, and Gibault, Gaston, Valeurs des éléments magnétiques a l'Observatoire de Chambon-la-Foret [Loiret] au 1 er janvier 1938 [Values of magnetic elements at the Chambon-la-Foret observatory on January 1, 1938] : Acad. sci. Paris Comptes rendus, vol. 206, no. 11, p. 851, 1938.

Mean values of magnetic elements calculated from 1,488 hourly observations taken during December 1937 and January 1938 are given in a table. Disagreement of the mean values with the expected normal values is explained by the three important magnetic disturbances that occurred during January. $W$. $A$.

4449. Haalck, Hans, Über die physikalischen Ursachen des Magnetismus der Erde [On the physical causes of earth's magnetism] : Gerlands Beitr. Geophysik, vol. 52, no. 3/4, pp. 243-269, Leipzig, 1938.

After a brief description of the fundamental problem of terrestrial magnetism, the physical theory of the cause of the terrestrial $122188-39-2$ 
magnetic field is discussed. The second part of the article examines certain physical problems of terrestrial magnetism relating to the action exerted by the normal terrestrial field on the outer solid crust of the earth.-W. $A$.

4450. Koenigsberger, J. G., Natural residual magnetism of eruptive rocks: Terres. Magn. and Atmos. Electr., vol. 43, no. 2, pp. 119-130, Baltimore, Maryland, 1938.

The study of the magnetic behavior of rocks under the influence of the earth's magnetic field through a long interval of time and the study of the history of terrestrial magnetism by aid of the rocks and minerals is facilitated by a knowledge of some new facts connected: with physics, physical chemistry, mineralogy, and petrography. As the literature is scattered through many periodicals in various languages, the facts, which are not generally known, are summarized in this article. Some of these appear of interest in connection with the general theory of ferromagnetism. A long list of references is added.-W. $\boldsymbol{A}$.

4451. Lynton, E. D., Recent developments in laboratory orientation of cores by their magnetic polarity: Geophysics, vol. 3, no. 2, pp. 122-129, Houston, Texas, 1938.

During the past year further experimental work has increased the applicability of this method of orienting well cores by their magnetic polarity so that definite results now total approximately 60 percent of all cores tested, the presence or lack of heavy mineral grains being. the depending factor. The most important developments have been first, the elimination of human errors by making the recording apparatus entirely automatic and foolproof; second, the introduction of automatic and combined forward and reverse runs on cores, which enables the operator to distinguish definitely between polarized mineral grains and material with susceptibility only.-Author's abstract.

4452. Rooney, W. J., Lunar diurnal variation in earth-currents at Huancayoand Tucson: Terres. Magn. and Atmos. Electr., vol. 43, no. 2, pp. 107118, Baltimore, Maryland, 1938.

The lunar diurnal variation in earth-current flow at Huancayo andi Tucson has been determined from the records for the year 1932, near the sunspot minimum. Using the method employed by Chapman. for the magnetic elements, a definite lunar diurnal variation of markedly double period is found in both components of the potential-gradient at both stations. Harmonic analyses of the mean curves show that at Huancayo the amplitude of the second harmonic is about one-sixth that of the solar diurnal variation for the same year, while the amplitudes of the first, third, and fourth harmonies are negligibly small. At: Tucson the amplitude of the second harmonic is about one-fifth that of the solar diurnal variation for the northward component, which. is the principal component at that station.

The manner in which the lunar diurnal variation changes with the phase of the moon was also examined. For both components at Huancayo, curves constructed for the four main phases of the moon show a marked increase in activity during daylight hours and a corresponding diminution during the night so that the individual curves are no longer semidiurnal. For Tucson the curves for the individual phases of the moon, as determined from this single year's record are too irregular to show the changes definitely, but do indi- 
cate that they are less pronounced at this higher latitude station. As a check on this point the lunar diurnal variation at Tucson was redetermined by the method applied by Egedal to the data from Ebro. In this method the lunar diurnal variation is obtained from the records for the individual hours of the solar day. Using the hours from 12 to 24 , the lunar diurnal variation found is in good agreement with that obtained by the usual method. Comparing the lunar diurnal variation obtained separately by this method during daylight, $12^{\mathrm{h}}$ to $18^{\mathrm{h}}$, with that obtained during the night, $18^{\mathrm{h}}$ to $24^{\mathrm{b}}$, there is found only a slight decrease in amplitude from day to night and very little change in phase. These results are in agreement with those obtained by the first method and also with the revised conclusions reached by Egedal from his studies of the Ebro records.-Author's abstract.

4463. Bothé, J. P., Étude de quelques anomalies du champ magnétique terrestre [Study of some anomalies of the terrestrial magnetic field]: Jour. physique et radium, vol. 8, no. 7, pp. 895-905, 1937.

A brief review of magnetic measurements made in a few regions in Alsace-Lorraine and in northern France with the Schmidt vertical variometer manufactured by Askania-Werke. Detailed results of the date of measurements may be found in the Annales de l'Institut de physique du Globe de l'Université de Paris, vol. 15, no. 1, 1937, in which maps of anomalies are given. Local anomalies are, as a rule, related to layers at shallow depths. Deposits of basaltic, ophitic, and dioritic rocks were investigated. Some conclusions concerning the basaltic rocks are given. $-W . A$.

4454. Yanowsky, B. M., Temperature compensation of the uniflar by means of thermalloy: Terres. Magn. and Atmos. Electr., vol. 43, no. 2, pp. 143-147, Baltimore, Maryland, 1938.

The method of temperature compensation proposed by the author makes it possible to reduce the temperature coefficient of the magnetometer to zero; further it has advantages over the existing methodsmagnetic, optical, and mechanical-because it does not require supplementary arrangements in the magnetometer, thus simplifying in a considerable degree the construction of the magnetometer. The second advantage of the new method is that the compensation does not depend on the value of the magnetic field in which the magnetometer is placed.Author's abstract.

4455. Yanowsky, B. M., Application of the magnetic method of prospecting in the region of the mouth of the Selenga River and Lake Baikal [in Russian] : Bull. Neftianoy Geofiziki, no. 4, pp. 118-121, Moscow, 1938.

A series of magnetic maxima and minima was determined along the coast of Lake Baikal by a magnetic reconnaissance survey in 1932. The character and extent of the anomaly near the mouth of. the Selenga River was determined by a detailed magnetic survey in 1933 . The survey is described.-W. $A$.

\section{SEISMIC METHODS}

4456. Ayre, R. S., Interconnection of translational and torsional vibrations in buildings: Seismol. Soc. America Bull., vol. 28, no. 2, pp. 89-130, Berkeley, California, 1938.

An attempt has been made to provide an understanding of the v1bration of buildings in general form, that is, of those in which horl- 
zontal translation and rotation about vertical axes are interconnected. The principal point which it has been desired to bring out is that, in the general case, translation and rotation are coupled, the occurrence of one demanding also that of the other. With this object in view, the omission of a theoretical consideration of forced vibration seems justified here. The requirements for the independence of translation and rotation and the effects of various mass and rigidity distributions have been indicated. The free-vibration theory is summarized.Author's abstract.

4457. Benioff, Hugo, The determination of the extent of faulting with application to the Long Beach earthquake: Seismol. Soc. America Bull., vol. 28, no. 2, pp. 77-84, Berkeley, California, 1938.

An instrumental method is described for the determination of the extent of faulting in a given earthquake which depends upon the early arrival of $S$. If the faulting velocity is known, the exact extent is determined, otherwise, only upper and lower limits are given. Conversely, if the extent of faulting is known from field or other evidence, the faulting velocity is determined. The development given refers to a vertical fault exhibiting horizontal displacement, or, more generally, to a fault in which the displacement is parallel to the direction of extension. When the displacement is perpendicular to the direction of extension, as in simple vertical fault, the faulting impulse is propagated by shear waves. For this condition the shear waves from the end point can never arrive earlier than the wave from the focus. On the basis of these considerations, an observed early arrival of $S$ indlcates that the source is a fault movement in which the displacement is parallel to the direction of extension. In general, this would refer to a horizontal extension of fault slip, although for observers in the vicinity of the epicenter it could refer to a vertical fault movement originating in the depths and propagating upward. In applying this method to the Long Beach earthquake, the available evidence indicates that faulting extended from the focus approximately to Signal Hill, a distance of $27 \mathrm{~km}$ with a faulting speed of approximately $4.2 \mathrm{~km} / \mathrm{sec}$.Author's abstract.

4458. Bernard, Pierre, Relation entre la hioule sur la côte du Maroc et l'agitation microséismique en Europe Occidentale [Relation between the surf on the coast of Morocco and microseismic disturbance in western Europe] : Acad. sci. Paris Comptes rendus, vol. 205, no. 2, pp. 163-165, 1937.

The intensity of the surf along the northwest shore of Morocco and its connection with the intensity of microseismic disturbance in Strasbourg are examined. Distinct parallelism between the two phenomena is established from observations made during December 1932 and January 1933. It is proved that the disturbance in Strasbourg occurred always from 1 to 3 days uhead of the increase of the intensity of the surf in Morocco; this is explained by smaller velocity of the waves in water. The common source of the two phenomena is attributed to disturbances at great depths occurring especially to the south of Iceland and to the west of Great Britain and Portugal. The knowledge of the connection between the two phenomena may serve for the prediction of the increase in the intensity of the surf along the seashore of Morocco.-W. $A$. 
4459. Birch, Francis, Travel times for shear waves in a granitic layer: Seismol. Soc. America Bull., vol. 28, no. 1, pp. 49-56, 1938.

Travel times for shear waves in a layer of granite have been computed on the basis of recent laboratory work which permits an approximate evaluation of the variation of velocity with depth. The results are found to agree very closely with those of Leet (see abstract no. 4481), found by the method of timed blasts, for New England. The mean surface velocity of shear waves in granite having their focus at the surface is computed to be $3.52 \mathrm{~km} / \mathrm{sec}$. at $568 \mathrm{~km}$, decreasing to 3.26 at $25 \mathrm{~km}$; the curvature is shown to be too small to be easily recognized from records of near earthquakes. A depth of $15 \mathrm{~km}$ for the granitic layer is shown to be consistent with Leet's observation of pulses through a second layer.-Author's abstract.

4460. Bullard, E. C., and Grant, C. K., Design and testing of geophones and their amplifiers: Royal Astron. Soc. Monthly Notices, Geophys. Suppl., vol. 4, no. 5, pp. 341-350, London, 1938.

From a brief outline of the principles of construction of geophones of the moving coil type, the piezoelectric type, and the Benioff type, it is concluded that the Benioff type, in which the motion of the ground causes a change in the length of the airgap in a magnetic circuit, is the easiest to construct and use. Theory is given of the operation of geophones of this type and the principles of design of such instruments are explained, a description being given of the construction of an actual instrument and of the associated amplifier and oscillograph. An account is also given of the tests carried out to insure that the geophone and amplifier introduce no spurious frequencies into the records obtained and that amplifier and oscillograph are free from resonances and have a suitable frequency response.A. W., Sci. Abstracts, vol. 41, no. 487, 1938.

4461. Bullard, E. C., The theory of the Benloff selsmograph: Royal Astron. Soc. Monthly Notices, Geophys. Suppl., vol. 4, no. 5, pp. 336-340, London, 1938.

A vertical seismograph in which the motion of the ground produced an electromotive force by varying the gap in a magnetic circuit was described by Benioff in Seismol. Soc. America Bull., vol. 22, no. 2, pp. 155-169, 1932 (see Geophys. Abstracts 41, no. 985). The principle of this seismograph is treated mathematically with a view to devising methods of increasing its sensitivity. The instrument is shown diagrammatically. $-W . A$.

4462. Bullen, K. E., Ellipticity corrections to waves through the earth's central core: Royal Astron. Soc. Monthly Notices, Geophys. Suppl., vol 4, no. 5, pp. 317-331, London, 1938.

The author has recently published ellipticity corrections for the normal $P$ and $S$ earthquake waves (see Geophys. Abstracts 91, no. 3987). Much of the auxiliary material prepared during this work is an aid in the estimation of ellipticity corrections for other earthquake phases, and the present paper gives the results for some of the principal phases associated with the earth's central core. The corrections all assume that geocentric latitudes have been used in calculating epicentral distances.

Six tables give the actual corrections for most of the phases considered in this paper. $-W . A$. 
4463. Bullen, K. E., Ellipticity corrections to earthquake waves reflected at the central core: Royal Astron. Soc. Monthly Notices, Geophys. Suppl., vol. 4, no. 5, pp. 332-335, London, 1938.

Mathematical discussion is given for deriving the ellipticity corrections for the phases PcP, ScS, PcS, from the material in the paper dealing with the corrections for earthquake waves through the earth's central core (see abstract no. 4462, above).-W. $A$.

4464. Byerly, Perry, The earthquake of July 4, 1934: Amplitudes and first motion: Seismol. Soc. America Bull., vol. 28, no. 1, pp. 1-13, Berkeley, California, 1938.

A study of the [California] earthquake of July 6, 1934, has already been presented in a previous number of this Bulletin (see Geophys. Abstracts 91, no. 3990). In it the epicenter was located and travel times were discussed. In this article a further study based on the measurements of amplitudes and phase differences is made.

The distribution of the first motion of the $P$ waves for the earthquake of July 6, 1934, combined with knowledge of the general faulting trends of the region, leads to the conclusion that the earthquake was caused by movement on a fault bearing about N. $40^{\circ} \mathrm{W}$. and dipping about $84^{\circ} \mathrm{NE}$. The displacement vectors dipped about $26^{\circ} \mathrm{NW}$. The displacement consisted of a motion of the Pacific side northward and of the continental side southward, as in 1906. This suggests an extension of the fault which broke in 1906 in Humboldt County. A second interpolation would give a fault bearing N. $46^{\circ}$ W.-Author's abstract.

4465. Cohee, G. V., The recent impetus to oil prospecting in Illinois: Illinois Acad. Sci. Trans., vol. 30, no. 2, pp. 226-228, Springfield, 1937.

The necessity of application of geophysical methods of prospecting in the Illinois basin is emphasized as most of the subsurface rocks are completely hidden by a thick cover of glacial drift. Furthermore, most of the formations consist of sandstone and shale with obscure stratigraphic relations. A brief description of the reflection seismographic method is given. Thirteen parties worked in Illinois in April 1937. Four new oil fields were recently discovered: Bartelso, May 1936; Patona, January 1937; Clay City, February 1937; Cisne, March 1937. The last three fields were discovered on -structural features outlined by the seismograph. $-W$. $A$.

4466. Conrad, V., Atmospheric pressure variations as secondary cause of earthquakes: Union geod. geophys. internat., Travaux sci., nó. 15, pp. 118123, Toulouse, 1937.

For each epicentral region a choice of meteorological stations was made to obtain pressure changes prior to the earthquake and these changes were subdivided into combinations with rising, falling, or almost constant pressure. Examination shows that some foci react to intense pressure changes apparently because of geological structure but others do not react at all. It is not possible to assume quite generally that pressure changes are secondary causes of earthquakes.R. S. R., Sci. Abstracts, vol. 41, no. 485, 1938. 
4467. Coulomb, J., and Grenet, G., Electromagnetic siesmographs: Union géod. géophys. internat., Travaux sci., no. 15, pp. 146-150, Toulouse, 1937.

The theory of these instruments (see Geophys. Abstracts 71, no. 2348) is briefly recapitulated and examples are given of seismograms obtained therewith corresponding, under various arrangements, with a sinusoidal wave starting suddenly, the amplification being 1,000 fold.-C. A. S., Sci. Abstracts, vol. 41, no. 485, 1938.

4468. Ewing, Maurice, Woollard, G. P., and Vine, A. C., Geophysical investigations in the submerged and emerged Atlantic Coastal Plain, part 3 [abstract] : Geol. Soc. America Proc. for 1937, p. 80, New York, June 1938.

Seismic refraction measurements, from Princeton to Barnegat Bay, New Jersey, have been made as a continuation of similar measurements of the depth of the crystalline basement made at Cape Henry, Virginia, and Woods Hole, Massachusetts, in 1935. The standard technique for seismic refraction measurements was followed. The observed depths are in agreement with the well logs of two deep wells extending to the basement. A geologic section constructed from these measurements is in agreement with known geologic and gravitational data.

4469. Ewing, Maurice, Seismograph measurements on the ocean floor [abstract] : Geol. Soc. America Proc. for 1937, p. 80, New York, June 1938.

Seismographs, amplifiers, oscillographs, and timing apparatus were constructed which could operate antomatically on the ocean floor in 2,000 fathoms. Special bomb shells were used, making it possible to fire explosives at this depth.

Two cruises were made on the research ship Atlantis of the Woods Hole Oceanographic Institution, one for testing behavior of explosives under great pressures, the other for testing the performance of the entire apparatus. Three tests of the apparatus were made.

All component parts of the apparatus worked well, and the tests indicate that the proper attack on the problem has been selected. Despite the difficult nautical problems involved in placing the apparatus properly on the ocean floor, leaving it undisturbed during the actual measurement, and recovering it afterward, it is expected that geological data will be forthcoming on the next cruise.

4470. Fritzsche, Gerhard, Untersuchungen iiber die von Maschinen, Fảhrzeugen und Wind hervorgerufenen Boden- und Gebäudeerschïtterungen nach Registrierungen eines Benioff-Vertical-Seismographen [Investigations on the oscillations of the ground and of buildings produced by machines, vehicles and wind based on registrations made with a Benioff vertical seismograph]: Leipzig Univ. Geophys. Inst., Veröff., vol. 10, suppl. 1, pp. 1-81, 1937.

Sinuous oscillations of the ground produced by stationary steam engines mounted at great distances from a highly sensitive seismometer installed in the earthquake station of the Geophysical Observatory of the University of Leipzig were registered. They were chosen for a detailed investigation of ground amplitudes over an extended area.

The Benioff vertical seismometer was used for measurements. The method of operation of this instrument is described. Its proper period may be changed by adjusting its sensitivity. The oil damping used showed great dependence on temperature. Therefore, a change of the 
damping factor, which could not be neglected, was observed during measurements. A method is mathematically derived and tested by which the instrumental constants of the strongly damped pendulum could be determined with considerable accuracy.

Data from measurements at 36 stations were examined to determine possible distributions of the effect of oscillation, of the amplitude of the fleld, and of their relation to the subsurface geclogy. The calculated damping coefficients, which decrease with an increase of the distance from the center of excitation, are discussed. Oscillations occurring after the engine comes to a standstill provide information on the paths of the propagation of the waves in the ground. Oscillations produced by vehicular traffic and oscillations caused by railroad trains running at great distances and by trucks passing close to the station of measurements are investigated. Temporal distribution of the periods and the dying away of oscillations serve to disclose the effects of extinction and damping in the underground. Proper periods produced in buildings by engines and wind were determined at some stations.

Miscroseismic disturbance registered in the earthquake room of the observatory is in good agreement with the prevailing conditions of wind. It is shown that the oscillations of a well isolated building are transmitted to the seismograph to a very small degree only, but that variations of air pressure produced by the suction-effect of the wind in the recording room are perceptible.

The Benioff vertical seismograph proved to be very satisfactory for measuring oscillations. Transportable horizontal instruments and records, valuable especially with regard to measuring,oscillations of the engines, may be obtained.-Author's abstract, translated by W. A.

4471. Fuchida, Takata, An experimental method to solve the equation of motion of seismograph: Tokyo Imp. Univ., Earthquake Research Inst., Bull., vol. 14, no. 3, pp. 415-419, 1937.

An attempt is made to solve the equation of motion of the seismograph :

$$
{ }^{\prime \prime}+2 e^{\prime} x+n^{2} x=f^{\prime \prime}(t)
$$

The method of numerical calculation which has been adopted for solving the above equation cannot be used when $f^{\prime \prime}(t)$ is very complicated. The writer, therefore, tries to solve the equation experimentally. The solution by the experimental method can, however, be obtained only for the initial conditions:

$$
x=0, \dot{x}=0 \text { at } t=0
$$

The principle of the method and its experimental arrangement are discussed, and the results are shown in a number of figures.-W. $A$.

4472. Gassman, Fritz., Zur Theorie der Schwingungsmesser [Theory of vibrographs]: Gerlands Beitr. Geophysik, vol.. 52, no. 1/2, pp. 1-19, Leipzig, 1938.

The equation of the indicator of a vibrograph possessing one degree of freedom is obtained when translation or rotation of the ground occurs even if these movements cannot be regarded as small vibrations about a fixed point. Allowance has been made in the equation for 
the influence of the inclination of the apparatus on the frequency of its own vibrations. This equation is applied (1) to derive the constants of the apparatus, (2) to deal with small vibrations of the ground, translatory or vibratory, and thus with a vibrograph to determine completely these vibrations, and (3) to obtain a generalized equation to measure small vibrations in relation to a system of coordinates, not fixed, but moving in any translatory or vibratory way. The last applies to vibrations of a vehicle on land, in water, or the air, as well as to vibration measurements with a torsiograph. The results are applied to vibrations of a railway carriage moving on a curve.-Author's abstract.

4473. Geophysical Instrument Co., Washington, D. C. Seismic prospecting apparatus refraction type: Circular "C," $4 \mathrm{pp}$.

The apparatus described follows closely the design of that developed by. E. R. Shepard, of the United States Bureau of Public Roads, and is intended to discover conditions underground by seismic refraction. Specifications of the apparatus are given.-W. $A$.

4474. Gershanik, Simon, Resultados Seismometricos del Ano 1934 [Results of seismic measurements in 1934]: La Plata Univ. Nac., Observatorio Astronomico, Ser. geophis., vol. 6, no. 2, pp. 53-111, 1937.

Contains tables showing earthquakes observed during 1934, giving date, component, phase, hour, period, amplitude, notes concerning the phases, character of $\mathrm{P}$, and notes concerning epicenters (see also abstract no. 4483).-W. $A$.

4475. Gutenberg, Beno, and Buwalda, J. P., Geophysical investigation of Yosemite Valley [abstract] : Geol. Soc. America Proc. for 1937, p. 240, New York, June 1938.

In order to determine the bedrock configuration beneath the floor of Yosemite Valley a seismic reflection survey was made in April and May 1935 with California Institute of Technology equipment and in September 1937. with both Institute and Geophysical Engineering Corporation outfits. The 106 shotpoints for reflection and refraction were distributed from a point above Mirror Lake to a point west of El Portal. Distinct velocities of about $1.8,2.5,3.0$, and $5.2 \mathrm{~km} / \mathrm{sec}$. with good to excellent reflections indicate three sedimentary members resting upon the granite bedrock.

The upper layer extends from lower Tenaya Creek to a point below El Capitan; maximum thickness, about 300 feet. Second and third members are about 700 and 800 feet thick midway between Awahnee Hotel and Le Conte Memorial Lodge, giving a maximum depth to granite here between 1,500 and 2,000 feet. The granite surface rises nearly 1,000 feet westward and downstream between that place and Leidig Meadow, descends 300 to 400 feet to a midvalley point north of Cathedral Spires, rises about 300 feet to a point north of Cathedral Rocks, then descends gently and rises again near the diversion dam. Data are sparse for the area farther west, but another debris-filled depression in the granite surface, several hundred feet deep, occurs south of the Cascades. The uppermost layer in Yosemite Valley probably consists of post-Wisconsin stream and lake deposits; the second and third layers are probably morainal material of Wisconsin or greater age. 
4476. Gutenberg, Beno, and Richter, C. F., Observed times of the Montana earthquakes, 1935: Seismol. Soc. America Bull., vol. 28, no. 2, pp. 85-87, Berkeley, California, 1938.

Travel times for $P$ and $S$ are given in a table, together with residuals against the travel-time tables given by the authors in their first and second papers on seismic waves (Gerlands Beitr. Geophysik, vol. 43, 1934, and vol. 45, 1935 ; see Geophys. Abstracts 71 and 83, nos. 2350 and 3058).-W. A.

4477. Gutenberg, Beno, and Richter, C. F., $\mathbf{P}^{1}$ and the earth's core: Royal Astron. Soc. Monthly Notices, Geophys. Suppl., vol. 4, no. 5, pp. 363372, London, 1938.

Waves formerly identified as diffracted $\mathrm{P}^{1}$ can be accounted for more satisfactorily as ordinary refracted waves, provided that the velocity distribution within the core is assumed to be as follows: velocity increasing from about $8 \mathrm{~km} / \mathrm{sec}$. at the inside surface of the core to about $10.2 \mathrm{~km} / \mathrm{sec}$. about $1,950 \mathrm{~km}$ deeper, where there is a rapid but probably continuous increase with depth, the velocity reaching $11.4 \mathrm{~km} / \mathrm{sec}$. within $300 \mathrm{~km}$, then decreasing slowly to $11.3 \mathrm{~km} / \mathrm{sec}$. at the centre.

This hypothesis is in better accord with the occasional large amplitudes. The modified velocity distribution requires two additional reversals in the travel-time curve, which accounts for peculiarities in the observations of $\mathbf{P}^{1}$ near the focal distance (which remains unchanged at $142^{\circ}$ ). It also accounts for similar observations of SKP and $\mathbf{P}^{1} \mathbf{P}^{1}$ and is consistent with the observations of other waves passing through the core.-Authors' abstract.

4478. Hayes, R. C., Tilting of the ground at Kelburn, Wellington: New Zealand Jour. Sci. Technology, vol. 19, no. 10, pp. 625-628, Wellington, 1938.

Tilt records kept at the Dominion Observatory, Wellington, over the period October 1930 to March 1934 show marked diurnal and seasonal variations. The diurnal variation has a close correlation with the earth temperature at a depth of 1 foot. The seasonal variation also appears to be controlled mainly by temperature, but more records are required to confirm this assumption.

The most interesting feature of the records over this period is a progressive tilt to westward of at least 10 seconds of arc, which began sometime in 1932 and continued until the tiltometer was broken by the earthquake of March 5, 1934. The cause of this tilt is not definitely known, but it is suggested that part of it may have been due to movements preceding the earthquake of March 5, 1934, and part of it to temperature changes.

No definite connection has so far been established between the tilting of the ground at the Observatory and the occurrence of local earthquakes.-Author's abstract.

4479. Ivanov, A. G., Utilization of the data on the speed of drilling in applied seismics [in Russian]: Bull. Neftianoy Geofiziki, no. 3, pp. 123-129, Moscow, 1936.

Data on the speed of drilling in various places in the Union of Soviet Socialist Republics and especially those in the region of Kursk anomaly were compared with the results of seismic observations in the same regions. A definite relation was found between the position of layers with different velocity of propagation of seismic waves 
and the depths at which the speed of drilling changed abruptly. This fact may serve as an additional means of interpreting seismic observations. Careful investigation of conditions under which the drilling is done (instruments and methods used, change of the diameter of the hole, etc.) is, of course, required.-W. $A$.

4480. Jankow, K., Niveauänderungen im Schïttergebiet der Erdbeben in Südbulgarien am 14 and $18 \mathrm{April}, 1928$ [Changes of levels in the region of shaking resulting from earthquakes in South Bulgaria of April 14 and 18, 1928] : Zeitschr. Geophysik, vol. 14, no. 1/2, pp. 20-26, Braunschweig, 1938.

The location and geologic structure of the region affected by these two very strong earthquakes are briefly described. Accurate levels were determined in the region shortly before the earthquakes. The levels were redetermined one year after the earthquakes. A map drawn from the new data shows: (1) The levelling net; (2) lines representing the places of equal subsidence and equal elevation of the ground, and (3) the main faults formed at the time of the earthquakes. $-W . A$.

4481. Krrumbach, G., Über die Verwendung langperiodischer Seismometer [On the application of long-period seismometers]: Zeitschr. Geophysik, vol. 14, no. 1/2, pp. 14-20, Braunschweig, 1938.

Methods of operating long-period instruments are discussed, and a practical example of the installation of such an instrument $(200 \mathrm{~kg}$ seismometer) is given. It is shown that a horizontal seismograph of great proper period may be installed without great difficulties thus making possible the important investigation of long periods occurring in seismograms in case of "long waves." The use of instruments having different magnification is moreover desirable as the records of the normal instruments with great magnification are often not clear. Also, during very strong earthquakes the recording pen is thrown out of its bearings. The instrument discussed may be transformed into a normal station instrument with magnifications of about 80 times by lowering its proper period and lengthening the arm of the recording pen.-W.A.

4482. Leet, L. D., Travel times for New England: Seismol. Soc. America Bull., vol. 28 , no. 1, pp. $45-48,1938$.

In a previous paper (see Geophys. Abstracts 87, no. 3337), which will be described hereafter as paper I, there was given a preliminary analysis' of waves from timed quarry blasts at distances as much as $187.5 \mathrm{~km}$. Those data now have been augmented by records from the new installation of three Benioff components at Weston College, Weston, Massachusetts, and a vertical component Benioff at Williams College, Williamstown, Mass., as well as a large number of additional records at Harvard.

To the absolute travel times based upon direct observations of the time of firing, shown in paper $I$, there have been added those for new distances to Weston and Williamstown based upon times of firing computed from Harvard records of later shots from some of the original quarries. Record character at new distances in the critical zone beyond $152.5 \mathrm{~km}$ has also helped remove some of the uncertainties left by paper I, and new data have led to the discovery of an error of an even second in the time for $\mathbf{H}$ at $\mathbf{1 5 2 . 5} \mathrm{km}$. Results are shown in a figure.Author's abstract. 
4483. Lunkenheimer, Frederico, Resultados Sismometricos del Ano 1932 y 1933 [Results of seismic measurements during 1932 and 1933]: La Plata Univ. Nac. Observatorio Astronomico Ser. geofis., vol. 5, no. 4, pp. 151204 , and vol. 6 , no. 1 , pp. 1-52, 1937.

The two volumes contain tables showing earthquakes observed during 1932 and 1933, giving date, component, phase, hour, period, amplitude, notes concerning the phases, character of $P$, and notes concerning epicenters of the earthquakes (see also abstract no. 4474).-W. A.

4484. Martin, Henno, Die Beurteilung von Verkehrserschïtterungen [Determination of oscillations caused by traffic]: Schalltechnik, vol. 9, no. 2, pp. 13-16, Jena, 1937.

It is still impossible to make correct determinations of the force of oscillations caused by traffic owing to the difficulty of making a distinction between direct causes, as vehicle and surface of the road, and indirect causes, as oscillations of the underground and buildings. Earthquake scales and similar means used at the present time for such determinations are examined. Comparative curves of pure mechanical and pure electrical measurements of oscillations are given in an attempt to determine whether the displacement of the oscillations or the acceleration of oscillations should be measured. Finally a description is given of Terzaghi's coil balance for simple measurement of irregular settling of the ground.-Author's abstract, translated by W. A.

4485. Oks, Meyer, Influencia de la anisotropia elástica de los estratos en los cálculos sismográficos de refracción [Influence of elastic anisotropy of layers of seismic refraction calculations] : Bol. inform. petrol., vol. 15, no. 161, pp. 109-118, Buenos Aires, 1938.

In calculating the thicknesses of formations by the seismic refraction method horizontal and vertical homogeneity of each layer is considered. An elastic anisotropy in the vertical plane is assumed in this study, and the relation between the thicknesses is calculated according to the method generally usedi in computing anisotropy. The magnitude of errors produced by certain values of anistropy is studied. Graphs are given, permitting the calculation of the real thickness of layers based on the coefficient of anisotropy $\mathbf{K}$ and vice versa.-Author's abstract, trans:lated by W. A.

4486. Ostrovskij, A. E., Measurements of the rate of propagation of elastic vibrations on small bases: Acad. sci. U.R.S.S. Comptes rendus [Doklady], vol. 17, no. 7, pp. 357-360, Moscow, 1937.

The velocity of propagation of elastic vibrations, the knowledge of which is necessary in prospecting by seismic methods, can be determined by means of photofilm. However, this has been done hitherto only if the elastic waves run over a sufficiently long base line. A method is described which makes it possible to measure; with necessary precision, the rate of propagation of elastic vibrations on a small base by using relatively small specimens or rocks from drill holes. An outline of the method and diagrams showing the arrangement of the tests are given. According to this method, two electromechanical receivers are attached to the specimen at a known distance apart, and the time of traverse of

- the wave is measured by a specially designed vacuum-tube ballistic galvanometer circuit. 
The method was tested by measuring velocities in an iron bar. Two electromagnetic receivers were fastened to the bar and connected to the input of the vacuum tubes. The vibrations were generated by the impulses of a steel ball against the end of the bar. The rate of propagation of longitudinal elastic vibrations was found to be $5,180 \mathrm{~m} / \mathrm{sec}$., which is in agreement with the tabulated data $(5,100-5,450 \mathrm{~m} / \mathrm{sec}$.). The same method was used to measure the velocity of sound propagation in the air, employing telephone receivers with a tube amplifier. The results of these measurements were also found to approach the tabulated data $(330 \mathrm{~m} / \mathrm{sec}$. $)-W$. . A.

4487. Rothé, Edmond, Piezoelectric quartz seimograph: Union géod. géophys. internat., Travaux sci., no. 15, pp. 152-164, Toulouse, 1937.

After a sketch of piezoelectric properties of quartz and the method of their measurement, their application to a seismograph is described in some detail, and examples of the seismograms are given. The shocks measured resulted from various artificially produced disturbances.C. A. S., Sci. Abstracts, vol. 41, no. 485, $193 \%$.

4488. Sezawa, Katsutada, and Kanai, Kiyoshi, Polarization of elastic waves generated from a plane source: Tokyo Imp. Univ., Earthquake Research Inst., Bull., vol. 14, no. 4, pp. 489-504, 1937.

In acoustic problems, the shorter the transmitted waves compared with the length of the source, the more the wave transmission is polarized in the direction of movement of that source. The same phenomenon is observed in the case of the dissipating waves that accompany seiches in a bay. This article gives a mathematical solution of this problem in the seismological field for the following cases: (1) A plane source with normal disturbance; (2) a plane source with shearing disturbance in its plane; and (3) a plane source with normal disturbance of the same phase within the plane of the source.-W. $A$.

4489. Somville, O., New type of vertical seismograph: Union géod. géophys. internat., Travaux sci., no. 15, pp. 137-145, Toulouse, 1937.

The apparatus is of the Ewing type and the arm between the axis of rotation and the pendulum is bent as in the Wilip modification of it, but downwards instead of upwards. The arm, however, is partly supported by the spiral springs and partly by a system of articulated rods, the whole being adjustable. Diagrams, methods of adjustment, and several examples of seismograms obtained with the machine are given in detail.-C. A. S., Sci. Abstracts, vol. 41, no. 485, 1938.

4490. Thoenen, J. R., Earth vibrations from quarry blasts : Crushed Stone Jour., vol. 13, no. 2, Washington, District of Columbia, 1938.

Vibrations transmitted through the ground from blasts in a quarry are studied to evaluate their damaging effect on adjacent structures. After a brief history of the problem and a description of the seismometers used, the results are summarized, in the form of tables, on the following tests: (1) Quarry test results (speed, amplitude, frequency, and duration of seismic waves in various rocks); (2) correlation of amplitude, frequency, and duration; (3) effect of distance on amplitude; (4) effect of moisture on amplitude; (5) effect of amount of explosive charge on amplitude; (6) effect of geographic direction on amplitude; (7) effect of kind of explosive on amplitude; (8) effect of thick over- 
burden on frequency; and (9) a comparison of earthquake waves with waves from quarry blasts. In the last paragraph the results of tests in a limestone quarry are given. These mine tests were designed so that many of the variable factors present in quarry shooting could be entirely eliminated or their effects closely evaluated. $-W$. $A$.

4491. von Thyssen, Stephan, Ein neues piezoelektrisches, Vertikalseismometer [A new piezoelectric vertical seismometer] : Zeitschr. Geophysik, vol. 14, no. 1/2, pp. 11-14, Braunschweig, 1938.

A new seismometer is described whose simple construction makes it suitable for field work. The piezoelectric material of this vertical seismometer is seignette salt (Rochelle salt) instead of quartz. Sensitiveness to humidity is eliminated by inclosing the apparatus in an airtight box. The weight of the seismometer is about $0.3 \mathrm{~kg}$. A seismogram obtained by the new apparatus from a shot of $1.5 \mathrm{~kg}$ of explosive, $2,280 \mathrm{~m}$ distant, is given.-Author's abstract, translated by W. A.

4492. Tillotson, Ernest, The "high focus" earthquakes of the International Seismological Summary: Gerlands Beitr. Geophysik, vol. 52, no. 3/4, pp. 377-407, Leipzig, 1938.

The 20 earthquakes listed as "high focus" shocks by the International Seismological Summary have all been investigated individually and the results tabulated. It appears that in the majority of cases where the $\mathbf{S}$ residuals are very large, the multiple shock hypothesis is the one which can be upheld with most justification. In the best observed of these shocks practically all the stations read the $\mathrm{P}$ of the first shock, in which case it is an easy matter to determine the epicenter with the assistance of a good table for $\mathbf{P}$ waves. Should the first shock or shocks be feeble and emergent some stations miss the first $P$ and read the second or third, and in this case the determination of the epicenter is more difficult. Having obtained the epicenter, the $S$ residuals then sort themselves out into groups according to the initial times of the shocks, and it is possible to pick out misidentified pulses, which are the reflected and refracted waves. The test of the hypothesis is then to look at as many seismograms as possible and find all the $P$ and $S$ onsets for all the separate shocks. If they are all present where calculations indicate they should be, then the hypothesis is probably correct. A difficult set of seismograms to interpret fully would be those from two shocks separated in time by 20 secs. and having a distance between the epicenters of approximately 2 degrees. I have not come across a well-observed earthquake of this type.-Author's abstract. .

4493. Tsuboi, Chuji, The water surface of a lake as an indicator of crustal deformation: Tokyo Imp. Univ., Earthquake Research Inst., Bull., vol. 15, no. 4, pp. 935-943, 1937.

Observations were made along the $235-\mathrm{km}$ shore line of Lake Biwa, in Japan, where 36 recording or staff water gages used for civil engineering purposes are distributed. Since the erection of the water gages (1889) readings of the height of the water of the lake have been continuous. This observational material is studied from the viewpoint of the geophysicist, particularly with reference to the crustal deformations around the lake. The results of the study are presented in the form of tables and graphs, and the conclusion is drawn that a lake can be considered a large level by means of which tilts of the earth's crust may be detected. $-W . A$. 
4494. Voiutsky, V. S., Recording of the directed reflected waves [in Russian] : Bull. Neftianoy Geofiziki, vol. 4, pp. 93-102, Moscow, 1937.

The separation of the reflected waves from all the other wavessurface, refracted, etc.-recorded on a seismogram presents great diffculty. Filters based on the frequencies of the various waves are not always satisfactory, as the differences in the frequencies of the reflected and some other waves are very small.

A new method, the so-called method of differential receiving of oscillations, is proposed. The fundamental principles of the new method are discussed mathematically, and the results of the application of this method in the field are given. Seismograms obtained from the application of the differential method and of the method ordinarily used are shown for comparison.-W. $A$.

4495. Voiutsky, V. S., Contribution to the problem of seismic coring [in Russian] : Bull. Neftianoy Geofiziki, no. 4, pp. 103-117, Moscow, 1938.

The problem of utilizing seismic waves for coring boreholes is briefly discussed. The following two ways are proposed: (1) Lowering into the borehole a sound-producing device and determining the absorption of the sound waves by various rocks inside the borehole; (2) determining the velocity of elastic waves produced by shocks or small explosions inside the borehole; from the different velocities the horizons of different layers may be distinguished. Fundamental principles of both the methods and difficulties for practical application of them are discussed. Tests made in 1936 in one of the boreholes near Baku are briefly described.-W. $A$.

4496. Voiutsky, V. S., Vacuum tube voltmeter with a neon lamp as indicator [in Russian] : Bull. Neftianoy Geofiziki, no. 3, pp. 130-136, Moscow, 1936.

After the substitution of electrical seismographs for mechanical ones, laboratories which served the crews doing seismic work were to be equipped with radiotechnical apparatus necessary for investigating and testing the amplifiers and generators of electrical seismographs. The equipping of laboratories with vacuum-tuhe voltmeters became important. The author proposes the use of a neon lamp as indicator in the vacuum-tube voltmeter. A description of such a voltmeter is given and its advantages are discussed.-W. A.

\section{ELECTRICAL METHODS}

4497. Alpin, L. M., Differential curves of soundings [in Russian] : Bull. Neftianoy Geofiziki, no. 4, pp. 32-48, Moscow, 1937.

A detailed study of theoretical curves of soundings and, in particular, the determination of the dependence of the positions of the extreme prints of two-layer and three-layer curves from resistances and thicknesses of the layers is considered necessary. Although the application of theoretical calculations for the direct interpretation of the curves obtained by field measurements may present great difficulties, the data obtained from theoretical analysis may still be helpful for a more correct understanding of the properties of the curves obtained by soundings.

Theoretical analysis of the most simple two-layer curve of vertical electrical soundings is given. Coordinates of the bending points of these curves and the positions of the tangents to the curves at these points are determined. $-W . A$. 
4498. Alpin, L. M., and Schoenmann, S., Calculation of spontaneous polarization in boreholes [in Russian]: Bull. Neftianoy Geofiziki, no. 3, pp. 44-64, Moscow, 1936.

Calculations of potentials produced in boreholes by spontaneous polarization are made under the assumption that the electromotive forces are distributed regularly on the planes of separation of the layers and on the walls of the hole. Formulas for calculating the potentials are derived for a system formed by any number of polarized layers in an electrically homogeneous medium. Finally, diagrams of potential along the axis of the hole are constructed for various characteristic cases. These diagrams are analysed and compared with diagrams of spontaneous polarization in the borehole.-W. $A$.

4499. Bursian, V., On the distribution of the potential along the axis of the borehole due to the electromotive forces produced by diffusion [of contact] [in Russian]: Bull. Neftianoy Geofiziki, no. 3, pp. 65-81, Moscow, 1936.

Mathematical analysis of the distribution of the potential in a borehole traversing one or several horizontal layers in close contact with one another is given. The electrical field is considered to be due to the electromotive force produced by diffusion. This force is assumed to be localized on the surface of the contact of any two media. The solution of the problem is simple when the resistances of all the media traversed are supposed to be almost equal to the resistance of the mud in the hole. In this article mathematical discussion is given on the assumption that the resistances at the walls of the hole and of the mud are different.-W. $A$.

4500. Bursian, V., On the distribution of the potential along the axis of a borehole due to the electromotive forces produced by filtration [in Russian] : Bull. Neftianoy Geofiziki, vol. 3, pp. 82-102, Moscow, 1936.

The influence of filtration by which the distribution of the potential along the borehole may change considerably is discussed. A general case in which the resistivities of the layers and of the mud in the borehole are very different presents great mathematical difficulty; therefore the case is studied in which the resistances of the layers are assumed to be about equal to a certain mean value and the resistance of the mud is different from this value. Mathematical discussion of the problem is given.-W. $A$.

4501. Electrical geophysical device for direct depth determinations [editorial]: Mines Mag., vol. 28, no. 5, p. 213, Denver, 1938.

This note discusses an instrument called the Resistance Gradiometer, designed for the location of geological formations by virtue of their electrical conductivity.-W. $A$.

4502. Evjen, H. M., Depth factors and resolving power of electrical measurements : Geophysics, vol. 3, no. 2, pp. 78-95, Houston, Texas, 1938.

The use of depth factors in electrical prospecting is critically reviewed and is placed on a rational foundation by assigning new physical significance to the so-called apparent resistivities and potential drop ratios measured by electrical methods. It is shown that these measureables may be considered as broadly averaged representations of the distribution of electric images with depth. As a result, universal depth factors exist which may be calculated once for all for any given 
electrode arrangement. The depth factors are calculated for a number of commonly used electrode arrangements and are found to be smaller than generally assumed. The potential drop ratio method is shown to be superior to the apparent resistivity method in regard to depth of reference as well as to resolving power. The resolution by either method, however, is found to be entirely inadequate to give anywhere near the detail obtained with well logs. The new approach adopted in this paper leads to simple and practical methods of analysis and direct solution of the interpretation problem, which are illustrated. These methods are shown to have a useful field of application also in gravitational interpretation. The extent to which a detailed analysis may be justifiably carried is briefly examined. From the point of view of practicability it is reaffirmed that the best field of application of the electrical methods is the investigation of horizontal changes such as the mapping of faults and salt dome flanks.-Author's abstract.

4503. Fritsch, Volker, Zum Prinzip der Widerstandsverfahren der Funkmutung [Contribution to the principle of the resistance method of radio prospecting] : Elektrotech. Zeitschr., vol. 58, no. 46, pp. 1241-1242, 1937, Brïnn, 1937.

The ground switched on in the oscillating circuit by means of two antenna-like systems will in general possess a complex resistance caused by different values of resistance and capacity, thus giving various meanings to the results of measurement. The limits of these various meanings are investigated. They may not be the cause of the qualitative erroneous conclusions.-Riewe's abstract in Zeitschr. Geophysik, vol. 1.4, no. 1.2, 1938, translated by W. A.

4504. Goldsmith, L. M., Earth resistivity measurement: Petroleum Eng., vol. 9 , no. 7, pp. 68-74, 1938.

The application of the Megger ground resistance tester to the particular problem of protecting pipes from corrosion is examined. A description of the method used for the detection of corrosive areas is given. Schematical design of the method of measuring earth resistivity and curves showing the resistivity of both high- and low-resistance areas are added.-W. $A$.

4505. Jakosky, J. J., Continuous electrical profiling: Geophysics, rol. 3, no. 2, pp. 130-153, Houston, Texas, 1938.

Various electrical methods now used fall under two general headings-inductive and conductive. By use of the latter methods, any theoretical depth of current penetration may be obtained by employing a sufficiently great electrode separation. However, masking effects are usually present, due both to polarization and to electrolysis. These factors may be minimized by use of a "pulse" of current having a predetermined time-current relationship; also bothersome inductive effects are minimized by employing. a slow-rising ware front. The pulse is of long time interval to aroid any appreciable phase shift between the currents flowing along the surface (where the potential measurements are being made) and those flowing at depth (where the desired structural effect is to be obtained). Contrast and comparison is made between refraction seismic work and conductive methods of geoelectrical prospecting, with particular attention to the method of determining intensity-distance curves using a moving electrode. Optimum electrode configurations are described and briefly analyzed, as are the electrolytic 
temperature effects. The theory, operating technique, and interpretative technique of the continuous profiling method are given in detail. Diagrams and discussions illustrate the application of the method to detailed structural mapping, reconnaissance structural mapping, and fault location work. In some cases the method described is yielding satisfactory results in areas where other geophysical methods have failed to give interpretable data. The paper also presents a brief summary of the commercial work done during 1937, with the Jakosky pulse method.-Author's abstract.

4506. Kozin, K. P., and Kalenov, E. N., Application of electrical prospecting to the study of underground pipe-line corrosion [in Russian]: Bull. Neftianoy Geofiziki, no. 3, pp. 3-30, Moscow, 1936.

Results obtained from qualitative and quantitative determinations of losses caused by corrosion and the application of electrical methods of prospecting for preventing these losses are described. After the discussion of the process of corrosion, types of corrosion, and methods for determining the corrosive properties of the soil, the investigation of several pipe lines in the Union of Soviet Socialist Republics (BakuBatum and Grozny-Makhach Kala oil conduits) is described. The characteristics of Schlumberger's method are compared with other methods in regard to the investigation of the corrosion of pipe lines. $-W . A$.

4507. Kozin, K. P., Ozerskaia, M. L., and Sheinman, S. M., On the new method of electrical prospecting [in Russian] : Bull. Neftianoy Geofiziki, no. 4, pp. 3-31, Moscow, 1937.

Utilization of telluric currents in electrical methods of prospecting are discussed. Telluric currents are currents produced in the upper part of the earth's crust by various natural causes, mainly by earth's magnetic field and magnetic storms. It was found that the variation in the intensity of manifestation of the telluric currents is much greater than could be expected from regular causes. This is explained by the as. sumption that the intensity of these currents is directly related to the geological formations of the region.

The first part of the article deals with the theory of interpreting the data obtained from telluric current measurements. In the second part the authors give a description of their experimental work with this new method in the oil-bearing region of Djaksimay, which had already been investigated by gravimetrical, seismic, and electrical methods of prospecting. A geologic map of this region with profiles of telluric currents is added.

Conclusions are drawn that: (1) The telluric-current method cannot be used for determining the depths of nonconducting masses or for detailed prospecting; (2) the method may be used as a preliminary survey, as it is cheap and simple; (3) only a general idea of the structure can be obtained; (4) the anomaly of telluric currents above nonconducting masses depends mainly on the geometrical shape of the mass and does not depend on the rocks surrounding it. The interpretation of the data is difficult, as many solutions are possible; (5) the profiles of the intensity of telluric currents depend on the relief. Determination of anomalies caused by relief is possible to a certain degree and only when the electrical properties of the earth are known.

The application of the method described requires some technical improvements. $-W . A$. 
4508. Kozin, K. P., Electrical prospecting in regions with permanently frozen ground [in Russian] : Bull. Neftianoy Geofiziki, no. 3, pp. 31-43, Moscow, 1936.

The problem of applying the resistivity and natural current measurements in permanently frozen ground is discussed. Laboratory experiments revealed that rocks affected by permanent freezing still possessed electrical conductivity. Explanation of this phenomenon as well as that of generation of electrodynamic forces in the areas on which a degree of freezing is observed are given. The conclusion is drawn that both the above-mentioned methods may be successfully applied to the solution of some problems connected with hydrogeology, engineering, and economic geology.-Author's abstract.

4509. Löwy, Heinrich, and Ghali, M. M., The dielectric constant of metallic suspensions and the measurement of ore content: Gerlands Beitr. Geophysik, vol. 52, no. 3/4, pp. 334-343, Leipzig, 1938.

Experimental researches concerning the relation between the dielectric constant of mixtures and the concentration of metal therein and discussion of a formula of Poincare and formulas deduced from the theory of H. A. Lorent\%. Definitition of the "electrodynamic volume" and introduction of this idea in the theory of Lorentz. Formula for deducing from the dielectric constant of rocks the dielectric constant of rock material.-Authors' abstract.

4510. Maillet, Raymond, Prospection Géophysique des sols [Geophysical prospecting of the ground] : Inst. tech. bâtiment et travaux publics Annales, no. 5, 1.8 pp., September-October 1936.

General principles of the resistivity method are briefly outlined and the following examples of its application to dam construction are given: Dam in the valley of the Couze, the Foum-el-Guerza Dam, Littleton Dam, on the Connecticut River, Morrisburg Dam, on the Saint Lawrence River, Ariel Dam, on the Lewis River, study of the dam project in the port of Algiers.

Seismic methods and their application to the study of the valley of the Meurthe at Saint Nicholas du Port are discussed.-W. 'A.

4511. Migaux, L., Application of electrical methods to study of complex strurture at Le Tselfat, Morocco: Oil Weekly, vol. 90, no. 3, pp. 34-39, Houston, Texas, 1938.

Application of electrical diagrams to the correlation of strata in wells in areas of complex geologic structure is described. The example dealt with in this paper concerns the double fold of Le Tselfat in the Preriff, northwest Morocco, composed essentially of the formations at the base of the "Secondary" with an overburden of Miocene rocks. The Toarcian, principally a shaly formation, crops out along the axis of the eastern fold, which is the one discussed in this work. A systematic study of the Toarcian has been made by means of data taken from 25 wells ranging in depth from 329 to 4,965 feet. A standard electrical diagram drawn up by the comparison and synthesis of the 13 complete diagrams is given. Several dip determinations made at Le Tselfat with an electromagnetic dipmeter are summarized in a table. From the details furnished by electrical diagrams of three holes it was possible to obtain a precise idea of the formations traversed and to calculate the exact dip.-W. $A$. 
4512. Rose, R. B., Individual inductive geophysical ore explorations : Canadian Min. Jour., vol. 59, no. 4, pp. 189-191, Gardenvale, 1938.

After a brief description of the principles of the electrical method of prospecting the operating technique of the MT-SCOPE (Metallascope) in the search for ore deposits is discussed. 'Typical results of field study and varying proper interpretations are illustrated by accompanying graphs. $-W$. $A$.

4513. Schoenmann, S., Kuznetsov, M., Ozerskaia, M., and Shakina, M., Study of electrical coring of a series of thin layers of high resistance by. means of buffer probes [in Russian]: Bull. Neftianoy Geofiziki, no. 3, pp. 103-122, Moscow, 1936.

Investigations had shown that very thin layers of high resistance are often not recorded if probes generally used in electrical coring are applied. To correct this defect, the so-called buffer probes were tested.

A buffer probe is defined as a probe of any type furnished with discs of insulating material serving to increase the potential differences in the receiving electrodes. Two types of buffer probes were tested: (1) The inverse buffer probe, which is provided with one insulating disc between the receiving electrodes $M$ and $N$, and (2) the normal buffer probe with two insulating discs placed: one on the side of the feeding electrode $\mathbf{A}$ and the other on the side of the receiving electrode $\mathbf{M}$.

The effect of the buffer-dises is to force the current lines from the solution (mud) in the hole into the rocks and to increase the length of the path of the current between the two receiving electrodes.

The results of tests made with these two probes in the laboratory are summarized as follows: (1) The normal buffer probe is not suitable for electrical coring of a series of alternating thin layers. (2) The inverse buffer probe gives a sufficiently detailed resistance curve provided that a correct choice of the length of the probe and of the size of the buffer is made. True resistances of the layers cannot be obtained. (3) The diameter of the buffer placed between $M$ and $N$ must be about 0.8 of the diameter of the hole. (4) The thickness of the buffer must be about $0.8 \mathrm{MN}$. (5) The length $\mathrm{AO}$ (distance between the feeding electrode of the inverse probe and the middle of the section between receiving electrodes) must be adjusted to the thickness of the layers and the diameter of the hole. (6) MN must be as small as possible, about one-half of the thickness of the nonconducting layer.

(7) Small deteriorations of the buffer have no influence on the resistivity curve.

A number of experimental curves showing the fundamental properties of buffer probes are given.-W. $A$.

4514. Solovov, A. P., and Sergeev, E. A., Contribution to the question of coring by the method of electrode potentials [in Russian]: Bull. Neftianoy Geofiziki, no. 4, pp. 49-53, Moscow, 1937.

Based on experience obtained during prospecting work in which the "method of electrode potentials" was applied, the use of selected electrodes (Wahlelektroden) during the coring of oil boreholes is suggested. Electrodes reacting to the change in concentration of ions in sulphate and chloride solutions in boreholes are recommended. By means of them it seems possible to determine the position of the oil iayers as well as the places of the influx of water.-Authors abstract, translated by W. $\boldsymbol{A}$. 


\section{RADIOACTIVE METHODS}

4515. Evans, R. D., and Goodman, Clark, Substandards of very feeble radioactivity [abstract], Am. Physical Soc. Meeting, April 1938, Proc.: Physical Rev., vol. 53, no. 11, p. 916, Lancaster, Pennsylvania, 1938.

Accurate quantitative knowledge of the radioactive content of natural materials is essential in problems of geologic age, the earth's internal heat, marine sedimentation, and biological problems related to radium and thorium poisoning. The radium standards required for these analyses contain about $10^{-12} \mathrm{~g}$ Ra. Accurate standards at such low activities are difficult to establish. There has now been calibrated a substandard radium solution containing $0.780 \times 10^{-12} \mathrm{~g}$ Ra per cc, whose absolute radium content has been elaborately checked by six independent experimental methods. Using this standard, several gamma-ray standards in the range of $10^{-7}$ to $10^{-5} \mathrm{~g}$ Ra have also been calibrated. These are of particular use in artificial radioactivity studies and in quantitative radium poisoning investigations. Commercial standards in this range of activity cannot be trusted. By exchanging analyzed specimens with the principal workers on the natural radioactivity of ordinary materials, it is hoped to bring a measure of quantitative reliability to the data of terrestrial radioactivity. Systematic differences of several hundred percent among several laboratories have been found. These disclose faulty radium standards and will permit the revaluation of geologic age and radioactivity data published by these laboratories when their standards are rechecked. During the past 2 years about 20 workers in 8 countries have joined this international interchecking program for the revision of data and standards.

4516. Evans, R. D., and Goodman, Clark, Alpha-particle counting and geologic ages: Physical Rev., vol. 52, no. 3, p. 255, Lancaster, Pennsylvania, 1937.

The complete theory of alpha-particle counting for thin and thick sources has been developed and experimentally confirmed by the method of internal standardization (Physical Rev., vol. 48, no. 6, 1935, see Geophys. Abstracts 80, no. 2912). For thin sources the a-ray counting rate becomes a direct measure of the rate of production of helium, a-rays, and is determined with a photographic recording vacuum tube electrometer. The counting rate for ordinary rock sources is from $\mathbf{0 . 3}$ to 0.4 a particles per mg per hour. The helium content divided by the rate of production of helium gives a direct measure of the geologic age that is independent of the decay constants of the radioactive series. Age determinations of several rocks have been made.-W. $A$.

4517. Goodman, Clark, and Evans, R. D., A new physical method for the determination of geologic ages [abstract], Am. Physical Soc. Meeting, April 1938, Proc.: Physical Rev., vol. 53, no. 11, p. 916, Lancaster, Pennsylvania, 1938.

Description of new techniques for determining the rate of helium production in igneous rocks by direct counting of a-rays (Physical Rev., vol. 52, p. 255A, 1937), and for the removal and measurement of the helium accumulated in a rock specimen during geologic time (Physical Rev., vol. 51, p. 595A, 1937). These techniques have now been successfully combined into a rapid, absolute, entirely physical technique for the measurement of geologic ages of as much as about 400 million 
years which does not depend upon the measured decay constants of thorium and uranium nor upon any laboratory standards of radioactive content. For older rocks a radium determination is also made. This indicates the small correction necessary for the finite decay of uranium, actino-uranium and thorium during the lifetime of the oldest rocks. Direct comparison of this new "alpha-helium" method of age determination with the "radon-thoron-helium" method formerly employed by other workers (W. D. Urry, Jour. Chem. Phys. 4, 34, 1936, 4, 40, 1936; A. C. Lane and W. D. Urry, Geol. Soc. America Bull. 46, pp. 1101-1120, 1935) has: (a) confirmed the accuracy and reliability of the new absolute method; (b) disclosed an error of about 130 percent in the radium standardization employed in the previous helium age measurements, with consequent lowering of the helium time scale; (c) established the absence of any strong unknown natural a-ray emitters in igneous rocks.

4518. Grivet-Meyer, T., Penetrating component of cosmic radiation: Acad. sci. Paris Comptes rendus, vol. 206, no. 11, pp. 833-835, 1938.

In studying the properties of the hard component in cosmic radiation, Geiger counters surrounded by $10 \mathrm{~cm}$ of lead are used at depths equivalent to 10,30 , and $75 \mathrm{~m}$ of water. Results for the mass absorption coefficients are given in a table. The significance of the results is discussed.-G. O. B., Sci. Abstracts, vol. 41, no. 485, 1938.

4519. Kolhörster, Werner, [Cosmic radiation and magnetic storm of January 1938] : Naturwissenschaften, vol. 26, pp. 159-160, Berlin, March 11, 1938.

Measurements of the vertical intensity with two independent double coincidence counting sets over a period including the magnetic storm of January 16 and the aurora display of January 25 showed a pronounced fall in intensity corresponding to the accompanying variation in the earth's magnetic field in each case, a maximum fall in intensity of about 8 percent and 6 percent being observed on the two occasions respectively.-D. H. F., Sci. Abstracts, vol. 41, no. 485, 1938

4520. Landsberg, Helmut, and Ingham, A. I., Core testing by radioactive methods : Oil Weekly, vol. 90, no. 4, pp. 26-28, Houston, Texas, 1938.

Electrometric apparatus for measuring the radioactivity of oil-bearing sandstones is briefly described. For measuring weak radioactivity, a Geiger-Müller counter was used. Experiments have shown that within relatively thin layers considerable differences in radioactivity can be observed. If proof can be furnished that such differences are consistent over a large area, a sensitive criterion for the correlation of horizons may be available. If measurements are made immediately after the removal of the core from the well, any radioactive material present may be tested.-W. $A$.

4521. Pickering, W. H., The production of cosinic ray showers at great depths: Physical Rev., vol. 52, no. 11, pp. 1131-1134, Lancaster, Pennsylvania, 1937.

Experiments are described which prove the existence of cosmic ray showers consisting of at least three particles, at depths down to $30 \mathrm{~m}$ of water below sea level. The experiments also show that the number of showers decreases in much the same way with depth as the number of vertical coincidences. Even in the first few meters of water 
there is no marked falling off in the relative number of showers. The eftect of lead on the showers at great depths is also discussed.Author's abstract.

4522. Wilson, V. C., Cosmic ray intensities at great depths: Physical Rev., vol. 53, no. 5, pp. 337-343, Lancaster, Pennsylvania, March 1, 1938.

A fourfold Geiger-Müller tube telescope was employed to count the relative number of cosmic rays under different thicknesses of rock. Each Geiger-Müller tube consisted of a $0.125 \mathrm{~mm}$ tungsten wire anode and a cylindrical copper cathode $9 \mathrm{~cm}$ in diameter and $71 \mathrm{~cm}$ in length, sealed in a glass envelope filled with hydrogen to a pressure of 9.6 $\mathrm{cm}$ of mercury. The experiment was performed in a mine whose shaft was inclined at an angle of $34^{\circ}$ from the horizontal. Counts were made at 39 different stations at depths from zero to $1,408 \mathrm{~m}$ of water equivalent, where the rate was $5.7 \times 10^{-5}$ as great as at the surface. When the intensity is plotted against the depth, the resulting curve shows. no points of inflection. The effective absorption coefficient decreases from 0.07 per $m$ of water at the surface, to 0.0025 at the greatest depth. If the logarithm of the intensity is plotted against the logarithm: of the depth, two straight lines, one from 20 to 250 and the other from. 250 to $1,418 \mathrm{~m}$ water equivalent from the top of the atmosphere, represent the data well. Shower counts were also made at 10 of the stations. These also show a bend at $250 \mathrm{~m}$. This suggests that there may be two types of very penetrating rays both capable of producing showers. It may be that one of these consists of "heavy electrons" and the other of "neutrinos."-Author's aostract.

\section{GEOTHERMAL METHODS}

4523. Bullard, E. C., The disturbance of the temperature gradient in the earth's crust by inequalities of height: Royal Astron. Soc. Monthly Notices, vol. 4, no. 5, pp. 360-362, London, 1938.

The temperature gradients at six bores and at one point in the Simplon Tunnel are corrected for the influence of topographic irregularities. The correction is negligible for the bores and is 14 percent for the tunnel. Thus the correction need only be applied in very mountainous country.-Author's abstract.

4524. Kraskowski, S., Geothermal measurements: Geofizika, no. 6, pp. 13-58, Leningrad, 1934.

The author describes the development of applied geothermics and examines the results obtained. In chapter 1 be discusses the thermal conditions of the superficial strata of the earth, the diurnal and yearly fluctuations of temperature, as well as fluctuations of larger. periods of time. Factors influencing the distribution of the temperature in the ground such as thermal conditions of the soil, influence of vegetation, of the slope of the surface, and elevation above the sea level are examined. Chapter 2 is devoted to thermal conditions of the deep horizons of the earth. History of geothermal measurements made in Europe, Union of Soviet Socialist Republics, and the United States. is given. The relation between the depth temperatures and geologic structure is discussed on the basis of a map of the United States. showing the distribution of geothermal gradients (according to Van. 
Orstrand). Diagrams of geoisotherms and profles of a series of salt domes and oil fields in the United States are added. The results of measurements and the influence of oil, salt, and radioactivity on temperature causing the variation of geothermal gradients are discussed. Thermometers and equipment used for making geothermal measurements are described. Application of the thermometric method for solving some technical problems is briefly considered. In the last part of the article the author discusses computations from the data obtained and shows methods of graphical interpretation of geothermal measurements in boreholes. At the end of the article 114 titles are cited.W. $A$.

4525. Schlumberger, Marcel, and Poirault, A., Reconnaissance des terrains dans un sondage tubé par procédé thermométrique [Investigation of formations in a cased well by thermometric method]: Rev. pétrolifère, no. 783, pp. 537-538, Paris, 1938.

The development of the thermometric method of surveying cased oil wells in which electrical coring cannot be used is described. The basic principle of this method is that in a well filled with mud at either a lower or higher temperature than the formation temperatures, the mud will gain or lose heat in proportion to the heat conductivity of the adjacent formations. This transfer of heat will be more rapid in porous zones (sands) than in impermeable zones (shales). By lowering or raising an electrical temperature-measuring device through the column of mud these temperature differentials can be located and the presumptive pay horizons may be tested.

As an example the authors refer to a well that was drilled in Rumania in 1931 without any coring. In 1937 a survey was made by the thermometric method. This survey revealed a series of heat anomalies which were interpreted as indicating the presence of porous horizons. A parallel hole was drilled and logged electrically. The resistivity and spontaneous polarization data obtained coincide remarkably well with the results of the thermometric surveys. $-W . A$.

\section{UNCLASSIFIED METHODS}

4526. Aerial, geological, and geophysical survey of northern Australia, Parliament of Commonwealth of Australia, 91 pp., 12 pls., L. F. Johnston, Commonwealth Government Printer, Canberra, 1937.

This is a report of the committee appointed to direct and control the aerial, geological, and geophysical survey of northern Australia, for the period of one year ended December 31, 1936. Geophysical surveys made in several areas in Northern Territory and Queensland are described on pages $67-87$ of this report. Plates 5 to 12 showing plans and profiles are attached. The following methods were applied during the field season of 1936: (1) Electromagnetic, (2) potential, (3) self-potential, (4) resistivity, and (5) magnetic. A brief description of the principles of these methods is given.

Northern Territory.-(1) Tennant Creek: The instrumental equipment comprised two vertical magnetometers and one horizontal. An analysis of operations shows a total of 5,679 acres completed at an average rate of 177.5 acres per week, the average number of readings taken being 2.46 per acre. The results of the survey are summarized in a plate showing the position of all major anomalies. The magnetic 
method applied in the Tennant Creek gold field has proved very effective in locating lenticular ore bodies of hematite at various depths from the surface. (2) Brock's Creek: The greater part of the field work was done by the potential ratio method, which made possible the delineation of the nonconducting quartz veins. (3) Pine Creek district: Several small areas were surveyed by various methods. A brief description of the results in each area is given.

Queensland.-(1) The Croydon gold field: An area of about 1,600 acres was examined. Experimental traverses were made with the electromagnetic, self-potential, magnetic, and resistivity methods. Satisfactory results were obtained by electromagnetic and resistivity methods. (2) The iron range gold field, Cape York: This survey covered about 100 acres, and the instruments used were a vertical intensity variometer and a Thalen-Tiberg magnetometer. The results, presented on a contour map, yield much information concerning the structure of the area. The general trend of the high susceptible mineralized sedimentary rocks has been shown and some unsuspected ironstone deposits revealed. (3) The Dugald River silver-lead lode: The lode occurs in a belt of graphitic slates and schists, which strike approximately north. The object of the geophysical survey was to explore the possibilities of the existence of an extensive sulphide zone at depth and to locate and delineate, if possible, those portions of the lode where the mineralization may have been concentrated and where ore of higher grade might be expected. The following methods were used : electromagnetic, potential ratio, magnetic, and self-potential. Strong indications of the most favorable places to test the lode were obtained by the electromagnetic and self-potential methods. (4) The Silver Ridge lode, Kajabbi: This survey covered only 13 acres. The self-potential method gave reliable results and the negative potentials could be readily correlated with the known lode outcrops. The electromagnetc method gave unsatisfactory results. (5) Lolworth Creek gold field: The ore deposits occur in small greisenized areas in granite and consist of narrow lodes and stockworks, and the Midas and Mons Meg mines are pipelike bodies. Tests were carried out on these two mines by electrical, electromagnetic, and self-potential methods. The electrical (potential-ratio) method was the only one that was effective. (6) Trekelano: The survey of the Trekelano copper-gold mine was made chiefly by the electromagnetic method, which gave a large number of reactions, most of them due to causes other than ore bodies. It was shown by trenching that some of them arose from highly conductive zones in the schists. Surveying is still in progress so the results are not yet at hand. $-W$. $A$.

4527. Amaral, I., C. do, Generalidades sobre prospeção geofísica [Generalities about geophysical prospecting] : Mineração e Metallurgia, vol. 2, no. 11, pp. 331-334, Rio de Janeiro, 1938.

A brief review of the classification, problems, and methods of geophysical prospecting is given.-W. $A$.

4528. De Golyer, Everette, Future of petroleum exploration in the United States: Oil Weekly, vol. 35, no. 3, pp. 16-19, Houston, Texas, 1937.

The author belieres that the future of petroleum exploration lies in the organization of separate departments and the developing and refining of equipment and technique. Three definite and outstanding advantages 
should result from such a form of organization: (1.) Development of special equipment and technique for drilling exploratory or wildcat wells; (2) development of cost accounting and statistical control; (3) focusing attention on exploratory effort and fixing responsibility for success should advance materially the development and application of the technique of prospecting. $-W . A$.

4529. Geylikman, E. L., Gas survey in the region of Shubar-Kuduk [in Russian] : Bull. Neftianoy Geofiziki, no. 3, pp. 153-158, Moscow, 1938.

The results of the gas survey are given on a map of the region showing the distribution of the stations and the content of heavy hydrocarbons. Data obtained by the gas survey were compared with those of borings, and it was established that (1) the two sections in the Shubar-Kuduk containing commercial oil were determined with considerable accuracy ; (2) only a small hydrocarbon content was found in the oil-bearing region having no commercial value; (3) an area with increased content of heavy hydrocarbons was disclosed on the southern slope of the region.-W. $A$.

4530. Hubbert, M. K., The place of geophysics in a department of geology : Am. Inst. Min. Met. Eng. Tech. Pub. 945, 19 pp., New York, 1938.

Geophysics employs the knowledge and technique of the more fundamental science of physics to solve the problems of the more dependent science of geology. The institution of work in geophysics in departments of geology would go far toward correcting the present inadequate training of students in geology and bringing them more nearly abreast of the advances being made in earth science by people whose training has been primarily in the fundamental sciences.-Author's abstract.

4531. Karcher, J. C., Geophysical prospecting in petroleum exploration: Louisiana Eng. Soc. Proc., vol. 24, no. 3, pp. 97-107, New Orleans, Louisiana, 1938.

Four different geophysical methods-magnetic, electrical, gravimetric, and seismic-are used in petroleum exploration with reasonable success. A brief description of the principles of these methods is given. At present the seismic reflection method is the one most used in petroleum exploration. During the last several years the discovery of more than half the structural features capable of producing twenty million barrels of oil or more has been by geophysical methods. $-W$. $A$.

4532. Karcher, J. C., A review of the relation between physics and geology in petroleum exploration: Geophysics, vol. 3, no. 2, pp. 69-77, Houston, Texas, 1938.

The relation of the geologist and the physicist is discussed, and a brief review is given of the history of geology and physics in the broad sense for the best solution of the great problem of exploration for.new oil fields. $-W . \boldsymbol{A}$.

4533. Kelly, S. F., Geophysical prospecting: Canadian Min. Jour., vol. 59, no. 5, p. 200, Gardenvale, 1938.

Electrical and magnetic geophysical methods applied to the discovery of gold-quartz ore in Porcupine district, Ontario, are described. Geologic interpretation of results of an electrical and magnetic geophysical survey is shown on a map.

The contact between the lavas and sediments was surveyed by mag. netic methods and predicted to lie between 330 and 300 feet north of the claim line. Only two drills tested the area, which was found to 
lie between 320 and 300 feet.north of the claim line. Two zones of faulting or dislocation shown as a result of the electrical measurements were later found by drilling to be at the predicted places.

The survey demonstrates the manner in which geophysical methods can aid in the exploration of gold prospects, outlining zones to be trenched or drilled to determine the presence and the extent of commercial ore. $-W$. $A$.

4534. Lahee, F. H., Wildcat drilling in 1937: Oil and Gas Jour., vol. 36, no. 44, p. 41, Tulsa, Oklahoma, 1938.

Statistics on wildcat drilling during 1937 in southeast New Mexico, Texas, Louisiana, southern Arkansas, Mississippi, Alabama, and Florida are given. Footage drilled in productive and unproductive wildcat tests during 1937 is shown on a map and table. The results of drilling are summarized as follows: (1) Fifty producers and 414 dry holes were located on geologic information (surface, subsurface, trend, core drilling). (2) Fifty-three producers and 138 dry holes were located on geophysical evidence (seismograph, torsion balance, magneto-meter, gravity meters, or combinations). (3) Nine producers and 43 dry holes were located on combined geological and geophysical evidence. (4) Thirteen producers and 220 dry holes were pure wildcats, with neither geology nor geophysics to guide the selection of their sites. $-W . A$.

4535. McNish, A. G., Utilitarian aspects of geophysics: Sci. Monthly, June, pp. 495-507, Lancaster, Pennsylvania, 1938.

The ways in which geophysics may be of service to civilization are classified in the following three categories: (1) Direction toward a more economical exploitation of natural resources; (2) prediction of natural phenomena and recommendation as to the most effective means of avoiding or taking advantage of their effects; (3) actual methods of avoiding unfavorable occurrences and finding favorable ones, which, speculative as it may seem, are not outside the bounds of possibility.

A discussion of the value of geophysics is presented under the subdivisions meteorology, hydrology, oceanography, geodesy, seismology, volcanology, terrestrial magnetism, terrestrial electricity, and atmospheric electricity. $-W . A$.

4536. Mills, Brad., Setting two new depth records: Oil Weekly, rol. 89, no. 7 , pp. 30-64, Houston, Texas, 1938.

A description is given of the method of drilling by the Continental Oil Co. of K. C. L. A-2, the world's deepest well. The well is 15,004 feet deep and produces oil from 13,100 feet, thus exceeding all previous records for both drilling and production depths. A map shows the location of the well near Wasco, San Joaquin Valley, California. Important geologic data concerning formations below 12,000 feet procured by this drilling are given in a table. Electrical logging was an important factor in identifying and correlating formations. Oil was produced at 13,100 feet, where the electrical log showed good "porosity" and "resistance" characteristics. The temperature was above $260^{\circ}$ at a depth of 14,200 feet. Three temperature checks at 15,000 feet averaged from $268^{\circ}$ to $270^{\circ}$. The average gradient was about $1^{\circ} \mathrm{F}$. for each 125 feet, but the rate of increase near the bottom was slightly higher than above 10,000 feet. Checks on the indicated temperatures were made by running metals that melted at known temperatures. (See also abstract no. 4542.) $-W . A$. 
4537. Mitera, Z. A., Exploration in Poland: Mines Mag., vol. 28, no. 6, pp. 251252, 275, Denver, Colorado, 1938.

Geophysical progress since the introduction of geophysical methods of prospecting about 15 years ago is briefly described. Gravimetric, magnetic, refraction seismic, electrical, and finally the reflection seismic methods (1934) were used. Most of the work was done by the Pioneer Institute of Applied Geophysics.

A map showing the areas surveyed by the various methods is given: According to geologic investigations there are possibilities of finding new oil deposits in the western part of Poland adjoining the German boundary where several salt domes are known and where the geologic conditions are very similar to those in the northwestern German plains near Hannover.

It is concluded that Poland offers a fine field for the application of different geophysical methods in determining the existence of structural features favorable for the accumulation of oil and gas. $-W$. A.

4538. Mogilerski, G. A., Measurement of gases in boreholes [in Russian] : Bull. Neftianoy Geofiziki, no. 4, pp. 86-91, Moscow, 1937.

It is proposed to supplement data obtained by a gas survey of a certain region by investigating gas phenomena along vertical lines. A special apparatus for extracting gas from cores of rocks penetrated by a borehole is described.- $W . A$.

4539. Mogilevski, G. A., Influence of meteorological conditions and conditions of the soil on the content of soil gas [in Russian]: Bull. Neftianoy Geofiziki, no. 3, pp. 159-198, Moscow, 1936.

Field methods of a gas survey are discussed. Tests described show considerable variation in the composition of soil gas caused mainly by variations of temperature, atmospheric pressure, and moisture of the ground. Methods of possible elimination of meteorological factors are examined. Influence of topography upon these factors is discussed.W. A.

4540. Prospects of a Free State Witwatersrand [editorial]: South African Min. and Eng. Jour., vol. 49, no. 2363, pp. 353-354, Johannesburg, 1938.

Important discoveries are reported as results of drillings started at places indicated by geophysical surveys. One borehole passed from the overlying Karroo formation into quartzite and grits, probably belonging to the Witwatersrand System, at a depth of 991 feet. At a depth of 1,896 feet the drill entered a steeply dipping conglomerate reef zone. Another borehole passed from the Karroo formation into steeply dipping shales at a depth of 1,032 feet. In connection with the location of these boreholes geophysical surveys were first made over a large area of 91,858 morgen (194,071 acres) in order to determine the more favorable smaller areas for exploration. Torsion-balance measurements at 2,481 stations were completed and 47 miles of magnetic traverses were made. Satisfactory reef values encourage further investigations. $-W . A$.

4541. Rosaire, E. E., Shallow stratigraphic variations over Gulf Coast structures: Geophysics, vol. 3, no. 2, pp. 96-121, Houston, Texas, 1938.

Depth predictions for geophysical data obtained at the surface of the earth are usually made with the tacit assumption that lateral variations in the intervening strata are negligible. However, the 
evidence at hand indicates that, over Gulf Coast structures, local mineralization has resulted in appreciable stratigraphic variations which are not inverse functions of the depth or direct functions of the relief of the underlying structures, but do appear to be excellent indices of the areal extent of deep-seated, low-relief traps.

More than a generation ago evidence for this mineralization over and around Gulf Coast oil field was recognized in the induration responsible for lowered drilling rates and in the characteristic "halo" or "aureole" pattern of surface gas seeps. This mineralization results in increased acoustic speeds in the sediments overlying Gulf Coast traps, and so was responsible for the marginal refraction anomalies: discovered from 1928 to 1930 and has been indicated indirectly by the exaggerated relief frequently predicted by the reflection surveys made in this area to date. This mineralization also modifies the electrical properties of the shallow sediments and has been responsible for the shallow anomalies discovered by the recently introduced electrical transient method. Recent studies of the distribution of hydrocarbons and associated significant constituents in the surface soils have rediscovered and confirmed the "halo" pattern of surfáce gas seeps responsible for the discovery of the Goose Creek oll field in 1907.

The recognition that these stratigraphic variations occur at shallow depths even over low-relief, deep-seated structures should result in a material simplification in exploration procedure through affording more easily attainable objectives in the way of shallow but important clues to deep-seated traps.-Author's abstract.

4542. Sanders, T. P., Deep well is proving ground for newest methods: Oil and Gas Jour., vol. 36, no. 50, pp. 46-50, 55, and 66, Tulsa, Oklahoma, 1938.

Search for oil near Wasco in the San Jouquin Valley, California, was started about 2 years ago when a seismograph survey revealed. the presence of a dome at depth. A map shows the location of a 15,004-foot well, the deepest in the world, which was drilled by the Continental Oil Co., and which produces oil at the rate of 3,000 barrels a day. The method of drilling is described, and summarized geologic. data of the well are given in a table. The temperature at 14,000 feet was $268^{\circ}$ F. (See also abstract no. 4536 .) $-W . A$.

4543. Smith, H. I., The application of geophysics to hydraulic mining: Calffornia Min. Jour., vol. 7, no. 9, p. 14, Auburn, 1938.

Geologic factors such as the trend of the channel, thickness of the gravels, lava cappings, and depth to bed rock are usually disclosed in. solving the problem of hydraulic mining, but often there are unknown tributaries to these channels that contain rich deposits. The possibility of the location of these hidden channels by the proper application of geophysical methods is briefly discussed.-W. $A$.

4544. Sokolov, V. A., and Krugliakova, P. P., Microanalysis in gas survey [in Russian] : Bull. Neftianoy Geofiziki, no. 4, pp. 72-77, Moscow, 1937.

After a brief outline of the usual microanalysis made for determining the heavy and light fractions of hydrocarbons and their combustion in the samples taken for gas survey, a special apparatus is described for use in more detailed analysis as well as for the determination of the composition of the heavy fractions and the products of their combustion. A schematical design of the apparatus is given.W. $A$. 
4545. The Western Holdings and Geophysics [editorial]: South African Min. and Eng. Jour., vol. 49, no. 2364, pp. 395-396, Johannesburg, 1938.

Writing of local geophysical possibilities, the author mentions the new developments in the Free State (see abstract 4540). The services rendered by geophysical methods on the Witwatersrand in exploring geologically little known or problematical areas are summarized as follows: (1) Starting from some outcropping geological marker, this marker can be traced into adjacent ground covered by several thousand feet of younger formations. This was done in western Witwatersrand areas. Thus geophysics may be said to act as an identifying or correlating device. (2) For the Witwatersrand problems in the broader sense the most important point is the use of geophysics in revealing the tectonics of a given area.-W. $A$.

4546. Tucker, Mitchell, Soil analysis surveys being made as an aid in geophysical studies: Oil and Gas Jour., vol. 37 , no. 6, pp. 20-22, 39, and 106, Tulsa, Oklahoma, 1938.

In the search for petroleum the new method, of "soil analysis" as an additional exploratory tool is described. The process employs geochemical determinations in geophysical interpretations. The principal concepts of the theory are as follows: (1) Hydrocarbons from oil and/or gas deposits filter upward through the earth, regardless of depth or occurrence of supposed impervious formations; (2) from soil samples taken at or near the surface, laboratory analyses can be made which will indicate relatively the quantitative hydrocarbon value of each; (3) through perfected means of interpretation, these relative findings can be plotted and correlated with sample stations on the surface in such a way as to indicate structure and the probable presence of petroleum below. The procedure is described in the following steps: (1) Field sampling technique; (2) laboratory analysis; (3) mathematical calculations and graphs; and (4) interpretation of each of the several different types of structural features containing petroleum.-W. $A$.

4547. Zagarmistr, A. M., Geophysical prospecting for gold-bearing quartziferous veins [in Russian] : Bull. Neftianoy Geofiziki, no. 4, pp. 122-156, Moscow, 1938.

An attempt is made to analyze the geophysical methods of prospecting applied in the Znameniti mine, in the Alatau Mountain Range in Siberia, and to establish a criterion for the selection of the most suitable combination of geophysical methods depending on the geologic conditions of the region containing quartziferous deposits. Magnetic and electrical methods were tested and the conclusion is drawn that the electrical methods have given the best results.

The article is illustrated by profiles, maps, and tables showing the results of magnetic and electrical measurements. $-W$. $A$.

\section{GEOLOGY}

4548. Boon, J. D., and Albritton, C. C., Jr., Established and supposed examples of meteoritic craters and structures: Field and Laboratory, vol. 6, no. 2, pp. 44-56, Dallas, Texas, April 1938.

At present no one can say how many meteorite craters are to be found on the earth; nor can one say how many scars recording geolog- 
ically ancient falls exist in the rock layers of the crust. It is, however, significant that the number of recognized craters is rapidly increasing. The variety of geomorphic and structural features which have been assigned either surely or tentatively to the impact and explosion of giant meteorites is demonstrated.-W. $A$.

4549. Boon, J. D., and Albritton, C. C., Jr., The impact of large meteorites: Field and Laboratory, vol. 6, no. 2, pp. 57-64, Dallas, Texas, April 1938.

The discussion gives a roughly quantitative idea of the tremendous resistance the earth offers to penetration by giant meteorites. At the instant of maximum penetration a meteoritic projectile is seated on a charge of material that is heated and compacted beyond comprehension. It is difficult, therefore, to conceive how meteorites, after driving into the earth to depths of hundreds of thousands of feet, could escape being blown back out of the ground and shattered.-Authors' summary.

4550. Weller, J. M., and Bell, A. H., Illinois Basin : Am. Assoc. Petroleum Geologists, vol. 21, no. 6, pp. 771-788, Tulsa, Oklahoma, 1937.

Structural history.-The Illinois basin is part of a larger basin which during Paleozoic time extended an unknown distance southward. The greater part of the relative uplift of the borders of the Illinois basin probably occurred at the end of the Paleozoic era during the Appalachian revolution. Major and minor structural features within the basin were formed at various times during the Paleozoic era; much deformation along the southern border of the basin was of post-Paleozoic age. The time of origin of the more important known structural features in the basin is discussed.

Exploration for oil.-The history of oil exploration in Illinois is briefly reviewed with special attention to the great southeastern Illinois field which to date ranks sixth in the United States in total production. During most of the 32 years after discovery of this field there has been little systematic exploration for oil in Illinois, but this has been due in large measure to the belief that oil production is probably only around the rims and not in the central parts of large structural basins. Discovery of the Mount Pleasant field in Michigan and numerous fields in western Texas and elsewhere has upset this belief; so that now many geologists and oil executives favor careful exploration for oil throughout the areas of large structural basins. Possible oil-producing formations in the Illinois basin and structural trends in the basin with relation to oil possibilities are discussed.

Since 1934 the central part of the basin has been explored scientifically by both geological and geophysical methods. The first discoveries after the recent activity have come in 1937; the location of three new oil flelds by seismograph surveys, two of which are in the deep basin area, appears to be the beginning of a new period of development.-Authors' abstract.

\section{NEW BOOKS}

4551. Geophysical exploration of the ocean bottom: Am. Philos. Soc. Proc., vol. 79, no. 1, 144 pp., Philadelphia, April 21, 1938 . Subscription, $\$ 3.00$ per annum, through the Secretary, 104 South Fifth Street, Philadelphia, Pennsylvania.

Symposium arranged by the American Geophysical Union held at the American Philosophical Society at Philadelphia, November 26, 1937. 
The following articles are published in the Proceedings: (1) The importance of geophysics to submarine geology, by R. M. Field, pp. 1-8; (2) New methods of marine surveying, by G. T. Rude, pp. 9-26; (3) Present status of the problem of submarine canyons, by $\mathrm{H}$. C. Stetson, pp. 27-34; (4) The technique of securing undisturbed core samples of the ocean bottom, by C. S. Piggot, pp. 35-40; (5) The Geological Survey's work on the Piggot North Atlantic deep sea cores, by W. H. Bradley, N. M. Bramlette, J. A. Cushman, L. G. Henbest, K. E. Lohman, and P. D. Trask, pp. 41-46; (6) Marine gravimetric methods and surveys, by Maurice Ewing, pp. 47-70; (7) Gravity anomalies and island arc structure with particular reference to the West Indies, by $\mathbf{H}$. H. Hess, pp. $71-96 ;(8)$ The role of earthquakes and the seismic method in submarine geology, by N. H. Heck, pp. 97-108; (9) Terrestrial magnetism and oceanic structure, by J. A. Fleming, pp. 109-126; (10) Round Table discussion, pp. 127-144.

4552. Handbuch der Funktechnik [Handbook of radiotechnics, with yearly supplements] Fortschritte der Funktechnik [Progress of radiotechnics], Frankhsche Verlagsbuchhandlung, Stuttgart, 1937.

The whole work consists of three volumes, price RM. 48. Two volumes are issued so far, vol. 1, price RM. 10.50 ; vol. 2, price RM. 11.50. Volume one contains the theoretical foundations of radiotechnics; vol. 2, Elements of constructing receivers and amplifiers; vol. 3, Practical applications and limitations.

4553. Rudolph, H., Der Einfluss der Sonne auf den elektrischen und magnetischen Zustand der Erde [Influence of the sun on the electrical and magnetic condition of the earth], 61 pp., Verlag Otto Hillmann, Leipzig, 1936.

Contents: Sunspots; aurora borealis and magnetic phenomena; aurora borealis theories; diurnal variations of terrestrial magnetism; the real cause of aurora borealis and the common source of all electrical phenomena on the earth; the curve of the path of heliocathode rays; Hess' penetrating radiation; the four-phase electrical fundamental process in the ionosphere of the earth ; intensity of electrical sun radiation; cause of air electric phenomena; the cause of the terrestrial magnetism; bibliography.

4554. 17th Internat. Geol. Cong., Leningrad, 1937, Abstracts of papers, 240 pp., United Sci. Tech. Pub. Office.

This book contains abstracts in English of papers presented at the 17th International Geological Congress held in the U. S. S. R. in 1987. The following abstracts concerning geophysical methods in geology are published on pages 181--196: (1) Arkhangelsky, A. D., Geological results of the general magnetometric and gravimetric surveys in the U. S. S. R. ;

(2) Koenigsberger, I. G., Surface geology and the determination of the center and depth of the surface of a disturbing body by geophysical methods according to the potential theory; (3) Hess, H. H.; Peridotite intrusions, gravity anomalies, and island arcs; (4) Mikhailov, A. A., Gravity survey of the U. S. S. R.; (5) Selsky, V. A., Study of the structure of the earth's crust according to geophysical data; (6) Veinberg, B. P., The probable inner structure of the earth ; (7) Bronstein, K. G., Some ideas on the connection existing between the geomagnetic and geological data; (8) Uemura, Kimio, Contribution to the results of geophysical prospecting recently employed in Japan; (9) Gorshkov, P. M., Knowledge on gravity in the eastern part of the U. S. S. R. ; 
(10) Pariysky, N. N., Investigation of temporary variations of gravity in the Caucasus; (11) Bronstein, $\mathbf{K}$. G., The Kursk magnetic anomalies; (12) Strona, A. A., Results and problems of magnetometric studies of the pre-Cambrian in the European part of the U. S. S. R.; (13) Lagrula, Jean, L'emploi de la gravimétrie dans l'étude de la structure géologique de l'Algérie [Application of gravimetry for the study of the geological structure of Algiers] ; (14) Gamburzey, G. A., Instruments for seismlc prospecting and ways of their perfection; (15) Lane, A. C., The initial point in measuring geologic time; (16) Vernadsky, V. I., Radio-geology and its significance for present-day geology ; (17) Khlopin, V. G., Radioactive methods for determining geologic age of some geological formations in the U. S. S. R.; (18) Starik, I. E., The age of the earth according to the radioactive data; (19) Starik, I. E., Critical survey of radioactive methods for determining geologic age; (20) Khlopin, V. G., Oxygen method for determining geologic age according to Prof. Lane; (21) Marble, J. P., Allanite (orthite) as an index of geologic age; (22) Gerling, E. C., Age determination of rocks and minerals by the helium method; (23) Permiakov, V. M., On the question of determining geologic age of minerals and rocks by the lead method; (24) Komlev, L. V., On the age of pegmatite dikes of North Karalia; (25) Kurbatov, L. M., On radioactivity of ferromanganese formations and determination of the rate of their formation by the radioactive method; (26) Kurbatov, L. M., Radioactivity of Dictyonema shales.

4555. von Srbik, R. R., Geologische Bibliographie der Ostalpen von Graubünden bis Kärnten [Geological bibliography of the East Alps from Graubünden to Kärnten], first installment, issued by the Deutscher und Österreicher Alpenverein [German and Austrian Alpine Society], J. Winkler \& Co., Innsbruck, 1937.

Volumes 1 and 2 were issued previously (see Geoph. Abstracts 87, no. 3498). This installment contains the most recent literature prior to 1937.

\section{PATENTS}

4556. System and method of distance and depth measurement; Willy Kunze, Bremen, Germany, assignor to Submarine Signal Co., Boston, Massachusetts, a corporation of Maine: U. S. patent 2,116,523, issued May 10, 1938.

This invention relates to a system for distance and depth measurement comprising, in combination, a sharply tuned high frequency compressional wave beam transmitter adapted to transmit a high-frequency beam of compressional waves, a piezoelectric receiver having a broad resonance within the range of the transmitter and adapted to receive compressional wave energy substantially from all directions, means operatively connected with said receiver for filtering out all compressional wave energy received below the frequency of the transmitter, amplifying means for amplifying the compressional waves of the transmitted frequency and means operatively connected both to said amplifier and said transmitter for controlling the moment of operation of the transmitter and responsive to the energy impressed by the amplifier for indicating the instant of the receipt of the compressional wave. Claims allowed, 4. 
4557. Apparatus for making geophysical measurements; Karl F. Hasselmann, New York, New York, assignor, by mesne assignments, to the Salt Dome Oil Corporation, Houston, Texas, a corporation of Delaware: U. S. patent 2,117,003, issued May 10, 1938.

This invention relates to apparatus for making geophysical measurements upon areas of the earth's surface covered by water which comprises a structure providing a watertight chamber, a support within and carried by the structure of said chamber, said support being arranged to haive mounted thereon a geophysical instrument, means for contacting said support and holding it against movement within said chamber, and means operable at will for releasing said support from said contacting means and causing said support to hold said instrument in operating position for different positions of the chamber with respect to the earth's surface. Claims allowed, 4.

4558. Apparatus for seismic surveying; Henry Salvatori, Hollywood, California, assignor to Western Geophysical Co., Los Angeles, California, a corporation of Delaware: U. S. patent 2,117,364, issued May 17, 1938.

This invention relates to apparatus for reflection seismic surveying comprising means for generating seismic waves, a large number of seismometers arranged in line with each other, said line being horizontally offset from the position of said generating means by a distance of from about 75 feet to about 1,000 feet, and extending in each of two directions from a point opposite said generating means, the end seismometers being substantially equidistant from said generating means, and means responsive to the reflected seismic waves received by the various seismometers for forming a record comprising a plurality of traces. Claims allowed, 12.

4559. Seismic surveying; Henry Salvatori, and James N. Walstrum, Los Angeles, California, assignors to Western Geophysical Co., Los Angeles, California, a corporation of Delaware: U. S. patent 2,117,365, issued May 17, 1938.

This invention relates to the method of profiling at least one subsurface stratum which comprises producing seismic wayes at a first source, receiving seismic waves from said first source after reflection from said stratum at two or more reception points spaced from said source and out of line therewith, recording the effects of said seismic waves as a plurality of traces on a common record; producing seismic waves at a second source spaced from said first source and out of line. with said reception points, receiving seismic waves from said second source after reflection from said stratum and said reception points, and recording the effects of said last mentioned seismic waves as a plurality of traces on a second common record, the length of the reflected wave path between said first source and one of said reception points being substantially the same as the length of the reflected wavepath between said second source and the other of said reception points, and said two reflected wave paths having substantially identical reflection points on said subsurface stratum. Claims allowed, 19.

4560. Gravimeter ; Haakon Muus Evjen, Houston, Texas, assignor to Shell Devvelopment Co., San Francisco, California, a corporation of Delaware: U. S. patent 2,117,471, issued May 17, 1938.

In a measuring instrument for the determination of gravity acceleration, a spring, a hollow body suspended from said spring, fluid in said 
body, a fluid conduit connected to said body and means whereby upon a change in the position of said body produced by a change in gravitational acceleration, a fluid flow alters the mass of said body increasing said initial change in position. Claims allowed, 7.

4561. Method of making geological explorations; Elton V. McCollum, Ponca. City, Oklahoma, assignor to Continental Oil Co., Ponca City, Oklahoma, a corporation of Delaware: U. S. patent 2,118,441, issued May 24, 1938.

This invention relates to a method of measuring intervals between buried geological layers from the earth's surface including the steps of generating waves at or near the earth's surface, receiving reflections of waves from buried geological layers at a point at or near the earth's. surface positioned close enough to the wave source to subtend small angles at the points of the geological layers from which reflections take place, measuring the time difference between reflections from separated geological layers, and determining the interval between said. layers irrespective of the time of origin of the wavest Claims. allowed, 3.

4562. Geophysical method of determining geological structures; Elton V. McCollum, and Lawrence F. Athy, Ponca City, Oklahoma, assignors to. Continental Oil Co., Ponca City, Oklahoma, a corporation of Delaware: U. S. patent 2,118,442, issued May 24, 1938.

This invention relates to a method of locating subsurface tectonic structures, including the steps of generating seismic waves, receiving. reflections of said waves at a plurality of spaced points at or near theearth's surface, recording said reflections upon a common record strip, measuring the time differentials between recorded reflections from. spaced geological formations, and determining the direction of angular divergence between tectonic layers from said time differentials, whereby errors contributed by near surface layers are substantially avoided. Claims allowed, 2.

4563. Improvements in and relating to apparatus for gravity determinations;: Axel Rudolf Lindblad, Stockholm, Sweden: British patent 469,159, issued July 20, 1937.

This invention relates to an apparatus for determining the force of gravity or variations in the same, of the type comprising a movable. body, the weight of which is balanced for instance by means of a spring arrangement, an electric or magnetic field or in some otherway and which in moving, influences the electric or magnetic fleld. in such a manner that the exact position of the body can be observed. in this field. The apparatus is enclosed wholly or partially within a. constant temperature container of known type. Claims allowed, 3.

4564. Improvements in or relating to torsion balances; Gewerkschaft Elwerath and Erich Reeh, both of Hannover, Germany: British patent 478,047, issued January 11, 1938.

This invention relates to torsion balances and particularly to means. by which the balance beam may be held against movement in the housing. According to the present invention, a torsion balance is provided with means whereby the housing can be moved relatively to the other parts of the balance in order that the beam may be held against. movement in the housing. When the housing comprises several casings or frames, all or some of these may be movable so that the hous-- 
ing is entirely or only in part movable. In a preferred arrangement, according to the invention, means are carried by the stationary parts of the balance to hold the balance beam in position when the housing has been displaced. The arrangement may be such that the housing upon an initial movement engages with the beam and said holdings means then engage with the beam to hold it against the housing. Claims allowed, 7.

4565. Verfahren zur Feststellung und Lokalisierung von Körpern im Untergrunde [Method of determining and locating bodies underground]; Seismos G. m. b. H., in Hannover: German patent 442,832, issued April 8, 1927.

This invention relates to the method of determining and locating bodies underground the electrical conductivity and dielectric constant of which differ from those of the formations surrounding them. The invention is characterized by the fact that at the regularly distributed accessible points in the space or on the surface of the earth through which the current flows the anomalies of phase distribution in space caused by these bodies can be determined in a known way by measuring the phase differences between the alternating current and the electromotive force producing it. Claims allowed, 2.

4566. Schweremesser [Gravity meter]; Dr. Karl Kilchling, Freiburg, Breisgau : German patent 654,176, issued December 13, 1937.

This invention relates to a gravimeter the mass of which is held by a spring and a multifibre suspension. An arrangement for producing tension, consisting of several filaments, is secured to the multiflbre suspension, its force being equal to that of the reversion of rotation of the multifibre suspension. This arrangement produces the untwisting of the suspension into the position of the measurement. Claims allowed, 4.

4567. Procédé pour déterminer la nature des terrains, et notamment de ceux traversés par un forage [Method of determining the nature of the ground, especially that penetrated by a borehole]; Gilbert. Deschatre, of France: French patent 823,099, issued January 13, 1938.

This invention relates to a method of determining the nature of the layers penetrated by a borehole or of liquids included in these layers, by disclosing mineralized and oil-bearing layers by means of the reaction of the electrical capacity of the layers upon an oscillator placed near these layers. This determination is obtained by the variations of frequencies or by the absorption of waves emitted by the said oscillator. The variations are observed on a receiver placed at a certain distance from the transmitter. Claims allowed, 6.

4568. Procédé pour déterminer les conditions régnant au-dessou de la surface du sol [Method for determining conditions underground]; Standard Oil Development Co., United States of America: French patent 823,163, Issued January 15, 1938.

This invention relates to a method for determining conditions underground by measuring the effects of polarization produced in the ground. First, normal potential between two electrodes placed into the ground is measured; then a known current is passed during a fixed period of time between these two electrodes so as to disturb the normal potential, and the change of the potential is measured. For studying boreholes a 
known current is passed during a fixed time between the two electrodes at least one of which is lowered into the borehole and the effects of polarization produced by this current are observed. By measuring the effects of polarization at different depths the correlation between the layers of two or more boreholes is established. Claims allowed, 7.

4569. Seismic method of prospecting; V. S. Voiutsky ; Russian patent 52,266, issued December 31, 1937.

This invention relates to the reflection method of prospecting. An arrangement is described by which the interfering electrical oscillations. produced in the seismograph and arriving immediately before the reflected waves are separated on the seismogram by means of a cathode lamp by which the relation of the amplitudes of oscillations having different intensity are increased so that the relation of the amplitude of reflected waves to the amplitude of the oscillations preceding them becomes greater than one. Claims allowed, 5 .

4570. Arrangement for seismic prospecting; V. S. Voiutsky and A. A. Drozdov; Russian patent 52,361, issued December 31, 1937.

This invention relates to an improvement in the method of seismic prospecting described in patent 52,266 , above. It concerns the reduction of the number of batteries necessary for the incandescense of lamps. Claims allowed, 1. 



\section{INDEX}

The figure in parentheses refers to the class in which the entry stands; see list in table of contents]

\begin{tabular}{|c|c|c|c|}
\hline & & & \\
\hline Ubritton, C. C., Jr. (8) & & Gershánik, Simon (3) & 4474 \\
\hline Alpln, L. M. (4) & 4498 & Gewerkschaft Elwerath (10) & 4564 \\
\hline Amaral, I. C. do (7) & 4527 & Geylikman, E. L. (7) & 4529 \\
\hline Am. Philos. Soc. Proc. (9) & 4551 & Ghali, M. M. (4) & 4509 \\
\hline Athy, L. F. $(10)$ & 4562 & Gibault, Gaston (2) & 4448 \\
\hline Ayre, R. S. (3) & 4456 & Goldsmith, L. M. (4) & 4504 \\
\hline & & Goodman, Clark (5) _._. 4515,4516 , & 4517 \\
\hline Bartels, J. (2) & 4445 & Grant, C. K. (3) & 4460 \\
\hline Baziuk, R. M. (1) & 4425 & Grenet, G. (3) & 4467 \\
\hline Bell, A. H. (8) & 4550 & Grivet-Meyer, T. (5) & 4518 \\
\hline Benfleld, A. E. (1) & 4427 & Gutenberg, Beno (3) _._._ 4475, 4476, & 4477 \\
\hline Benioff, Hugo (3) & 4457 & & \\
\hline Bernard, Pierre (3) & 4458 & Haalck, Hans (2) & 4449 \\
\hline Bersudsky, L. D. (2) & 4446 & Handbook of radiotechnics $(\theta)$ & 4552 \\
\hline Birch, Francis (3) & 4459 & Hasselmann, K. F. (10) & 4557 \\
\hline Boon, J. D. (8) & 4549 & Hayes, R. C. (3) & 4478 \\
\hline Bosler, Jean (2) & 4447 & Howe, H. H. (1) & 4431 \\
\hline Bullard, D. C. (3) & 4461 & Hubbert, M. K. (7) & 4530 \\
\hline (6) (6) & 4523 & & \\
\hline Bullen, K. E. (3) & 4463 & Ingham, A. I. (5) & 4520 \\
\hline an, V. (4) & 4500 & Ivanov, A. G. (3) & 4479 \\
\hline Buwalda, J. P. (3) & 4475 & & \\
\hline Byerly, Perry (3) & 4464 & Jakosky, J. J. (4) & 4505 \\
\hline G. V.. (3) & & - & 4400 \\
\hline onwealth of Australla, Parlia- & 9460 & $----n----$ & $\mathbf{4 4 3 2}$ \\
\hline at of $(7)$ & 4526 & ov, E. N. (4) & 4500 \\
\hline $\mathrm{ad}, \mathrm{V},(3)$ & 4466 & Kanai, Kiyoshi (3) & 4488 \\
\hline Continental Oll Co. (10) & 4562 & Karcher, J. C. (7) & 4532 \\
\hline Coulomb, J. (3) & 4467 & $\begin{array}{l}\text { Kelly, S. F. (7) } \\
\text { Kilchling, Karl (10) }\end{array}$ & $\begin{array}{l}4533 \\
4566\end{array}$ \\
\hline (1) $-1-n-n-n$ & 4428 & gsberger, J. C. (2) & 4450 \\
\hline De Golyer, Everette (7) & 4528 & rster, Werner (5) & 4519 \\
\hline Deschatre, Gilbert $(10)$ & 4567 & , K. P. (4) & 4508 \\
\hline Drozdov, A. A. (10) & 4570 & $\begin{array}{l}\text { Kraskowski, S. }{ }^{(6)} \\
\text { Krugliakova, P. P. (7) }\end{array}$ & $\begin{array}{l}4524 \\
4544\end{array}$ \\
\hline Louis $(2)$ & 4448 & abach, G. (3) & 4481 \\
\hline Evans, R. D. (5) & 4517 & Kunze, Willy (10) & 4556 \\
\hline Evjen, H. M. (4) & $\begin{array}{l}4502 \\
4560\end{array}$ & Kuznetsov, M. (4) & 4513 \\
\hline Ewing, Maurice (1) & 4429 & Lagrula, Jean (1) & 4433 \\
\hline 4468, & & $\begin{array}{l}\text { Lahee, F. H. (7) } \\
\text { Landsberg, Helmut (5) }\end{array}$ & $\begin{array}{l}4534 \\
4520\end{array}$ \\
\hline Tanselau, G. (2) & 4445 & Leet, L. D. (3) & 4482 \\
\hline hsche Verlagsbuchhandlung (9) & 4552 & Lindblad, A. R. (10) & 4563 \\
\hline , Volker (4) & 4503 & $\mathrm{k} k \mathrm{k}$, E. N. (1) & 4434 \\
\hline Fritzsche, Gerhard (3) & 4470 & , Heinrich (4) & 4509 \\
\hline Fuchida, Takata (3) & 4471 & $\begin{array}{l}\text { Lunkenhelmer, Frederico (3) } \\
\text { Lynton, E. D. (2) }\end{array}$ & $\begin{array}{l}4483 \\
4451\end{array}$ \\
\hline B) $-\ldots------$ & & & \\
\hline - & & rl (1) - & 4435 \\
\hline eent Co. (3) & 447 & ymond $(4)$ & 4510 \\
\hline
\end{tabular}




\begin{tabular}{|c|c|c|c|}
\hline \multicolumn{2}{|c|}{ Abstract } & \multicolumn{2}{|c|}{ Abstract } \\
\hline 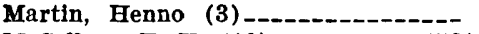 & & Sezawa, Katsutada (3) & 4488 \\
\hline llum, E. V. (10) & & Shakina, M. (4) & \\
\hline ish, A. G. (7) & 4535 & Sheinman, S. M. (4) & 4507 \\
\hline ux, L. (4) & 4511 & Shell Development Co. (10) & 60 \\
\hline Mills, Brad. (7) & 4536 & ank, O. A. (1) & 440 \\
\hline Mines Magazine (4) & 4501 & h, H. I. (7) & 4543 \\
\hline Mitera, Z. A. (7) & 4537 & Sokolov, V. A. (7) & 544 \\
\hline G. A. (7) & & $\begin{array}{l}\text { Solovov, A. P. (4) } \\
\text { Somville, O. (3) }\end{array}$ & $\begin{array}{l}4514 \\
4489\end{array}$ \\
\hline eumann, Frank (1) & 4436 & $\begin{array}{l}\text { South African Min. and Eng. Jour. } \\
\text { (7) }\end{array}$ & \\
\hline 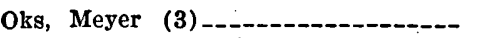 & & Standard Oll Development Co. $(10)--$ & \\
\hline E. (3) & 4486 & W. (1) & 4441 \\
\hline - & & e Signal Co. (10) & \\
\hline IG, & 4521 & (3) & \\
\hline Poirault, A. $(6$ & 4525 & $\begin{array}{l}\text { Tillotson, Ernest (3) } \\
\text { Tsuboi, Chuji (3) }\end{array}$ & \\
\hline 10) & 4564 & Tucker, Mitchell (7) & \\
\hline $\begin{array}{l}\text { r, C. F. (3) } \\
\text { y, W. J. (2) }\end{array}$ & $\begin{array}{l}4477 \\
4452\end{array}$ & United Sci. Tech. Pub. Office (9) & 4554 \\
\hline e, E. E. (7) & 4541 & R. W. & 442 \\
\hline 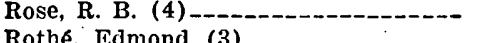 & $\begin{array}{l}4512 \\
4487\end{array}$ & Vening Meinesz, F. A. & \\
\hline (2) & 4487 & Vine, A. C. (3) & 68 \\
\hline & & V. S. (3) $-1--$ & \\
\hline $\begin{array}{l}\text { Oil Corporation (10) }-\overline{-} \\
\text { enry }(10)\end{array}$ & $\begin{array}{r}4557 \\
4559\end{array}$ & $\begin{array}{l}\text { von Srbils, R. R. (9) } \\
\text { von Thyssen, Stephan (3) }\end{array}$ & $\begin{array}{l}4555 \\
4491\end{array}$ \\
\hline (7) -- & 4542 & $(8)$ & 4550 \\
\hline annes ( & 4437 & stern Geophysical Co. (10) __ 4558, & 4559 \\
\hline Tarcel $(6)$ & 4525 & Wilson, V. C. (5) & 4522 \\
\hline 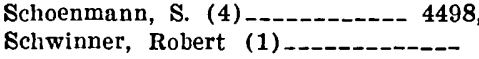 & $\begin{array}{l}45 \\
44\end{array}$ & Woollard, G. P. (3) & 4468 \\
\hline 0) _-_-_--- & & $\mathrm{ky}$, B. M. (2) & \\
\hline 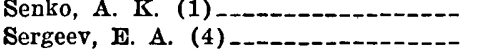 & & 7) & 4547 \\
\hline
\end{tabular}

